\title{
TAXONOMIC STUDY OF SCALLOPS (PECTINIDAE: MOLLUSCA, BIVALVIA) FROM PLIOCENE DEPOSITS (ALMERÍA, SE SPAIN)
}

\author{
Antonio P. JIMÉNEZ, Julio AGUIRRE*, and Pas- \\ cual RIVAS
}

\begin{abstract}
Departamento Estratigrafía y Paleontología. Facultad de Ciencias. Fuentenueva s/n. Universidad de Granada. 18002-Granada (Spain), and Centro Andaluz de Medio Ambiente, Avda. del Mediterráneo s/n, Parque de las Ciencias, 18071-Granada.

(* corresponding author: jaguirre@ugr.es)
\end{abstract}

Jiménez, A. P., Aguirre, J. \& Rivas, P. 2009. Taxonomic study of scallops (Pectinidae: Mollusca, Bivalvia) from Pliocene deposits (Almería, SE Spain). [Estudio taxonómico de los pectínidos (Pectinidae: Mollusca, Bivalvia) del Plioceno de la Provincia de Almería (SE España).] Revista Española de Paleontología, 24 (1), 1-30. ISSN 0213-6937.

\begin{abstract}
A taxonomic study has been carried out on scallops (family Pectinidae: Mollusca, Bivalvia) occurring in the lower-earliest middle Pliocene deposits of the Campo de Dalías, Almería-Níjar Basin, and Carboneras Basin (province of Almería, SE Spain). The recently proposed suprageneric phylogenetic classification scheme for the family (Waller, 2006a) has been followed. Twenty-two species in twelve genera (Aequipecten, Amusium, Chlamys, Flabellipecten, Flexopecten, Gigantopecten, Hinnites, Korobkovia, Manupecten, Palliolum, Pecten, and Pseudamussium) and three subfamilies (Chalmydinae, Palliolinae, and Pectininae) have been identified. This number of species is higher than previously reported for the same area. Additionally, the phylogenetic classification followed in this paper modifies the species attributions formerly used.
\end{abstract}

Key words: Pectinidae, taxonomy, Pliocene, Almería, SE Spain.

\section{RESUMEN}

Se ha realizado un estudio taxonómico de los pectínidos (familia Pectinidae: Mollusca, Bivalvia) de los depósitos del Plioceno inferior y base del Plioceno medio que afloran en el Campo de Dalías, Cuenca de Almería-Níjar y Cuenca de Carboneras (provincia de Almería, SE de España). Se ha seguido la clasificación filogenética recientemente propuesta por Waller (2006a) para niveles supragenéricos. Se han identificado veintidós especies distribuidas en doce géneros (Aequipecten, Amusium, Chlamys, Flabellipecten, Flexopecten, Gigantopecten, Hinnites, Korobkovia, Manupecten, Palliolum, Pecten y Pseudamussium) y tres subfamilias (Chalmydinae, Palliolinae y Pectininae). Este número de especies es mayor de lo que previamente se había registrado en esta misma área. Así mismo, la clasificación filogenética seguida en este trabajo modifica algunas de las atribuciones específicas anteriormente usadas.

Palabras claves: Pectinidae, taxonomía, Plioceno, Almería, SE de España.

\section{INTRODUCTION}

The family Pectinidae is the most diversified one of the pectinoideans in present-day oceans; it contains about 300 extant species in approximately 60 genera (Waller, 2006a). The family is well represented in modern oceans and includes representatives adapted to many different habitats and modes of life.
From a palaeontological perspective, the oldest occurrence of a member of the family is Early Triassic (Newell \& Boyd, 1995) and the group is recorded continuously onwards to the present. The presence of a mostly calcitic shell gives the pectinids a high fossilization potential resulting in this group of marine bivalves being one of the best represented in the fossil record. This circumstance has promoted a wealth of papers dealing with the use of 
pectinids in biostratigraphy, palaeoecology, and evolution. Although the supraspecific taxonomy of the group is under revision (see below), all these studies rely on relatively well-established species taxonomy.

Pectinids are among the major constituents of the marine invertebrate assemblages of the Pliocene deposits in the province of Almería (SE Spain). The relative importance of this group is enhanced because of the dissolution of most of the aragonite shells. They occur dispersed in the sediments as well as forming dense concentrations, both as the major components in factory deposits of carbonate platforms and in storm-bed deposits (Aguirre et al., 1996; Aguirre, 1998; Martín et al., 2004; Braga et al., 2006). In addition to these particular pectinid-dominated deposits, in the Almería-Níjar Basin, Amusium cristatum (Bronn, 1827) forms paucispecific beds of a few centimetres thick $(5-10 \mathrm{~cm})$ that can be laterally followed for hundreds of metres where individuals are densely concentrated (hundreds of individuals) (Aguirre et al., 1996). Some of these beds can be interpreted as shell-lag storm deposits, where specimens of A. cristatum show clear signals of reworking, such as high values of disarticulation, fragmentation and abrasion. In other cases, this species forms concentrations consisting of articulated and complete individuals, indicating absence of reworking. Therefore, these concentrations are interpreted as biological accumulations (sensu Kidwell et al., 1986).

To better determine the taxonomic composition of the pectinid assemblages of these deposits, Méndez-Cecilia (1971) carried out a preliminary study of species in different outcrops of the province of Almería based on material collected by students. She identified 16 species and 3 varieties, one of which was a new variety (Chlamys clavata var. almeriense Méndez-Cecilia, 1971). Apart from this taxonomic work, Demarq (1990) summarised the Neogene pectinids of the Betic Cordillera in a taxonomic list. Later, Aguirre et al. (1996) performed a palaeoecological study on the relationship between pectinid assemblages and the facies in which they occur in the Campo de Dalías and Almería-Níjar Basin. These authors provided the taxonomic composition and the relative abundance of pectinid species (Aguirre et al., 1996).

The generic attribution of many species, as well as the criteria for species identification, has changed since the taxonomic study of Méndez-Cecilia (1971). Further, the recent developments of pectinid taxonomy, based both on molecular and anatomical data, has introduced a new insight to and obliged us to revise our previous accounts of pectinids. Therefore, in this paper, we present an updated taxonomic revision of the species of the family Pectinidae in Almería Pliocene deposits made upon a rather accurate sampling with more precise stratigraphic and palaeogeographic frameworks. The data presented herein will add information to the pectinid species richness and the palaeogeographic distribution of species in the Iberian Peninsula.

\section{LOCATION AND GEOLOGICAL SETTING}

The studied materials crop out widely in the Campo de Dalías or Poniente Almeriense, in the Almería-Níjar Basin and in the Carboneras Basin (Fig. 1). In the former, the Pliocene deposits are exposed in a mapped band south of Sierra de Gádor, between Adra and El Sabinar (Fig. 1a). In the Almería-Níjar Basin, the Pliocene deposits crop out widely in an area surrounded by Sierra de Gádor to the west, Sierra Alhamilla and Sierra Cabrera to the north, and by the volcanic province of Cabo de Gata to the east (Fig. 1b). In the Carboneras Basin, the Pliocene sediments occur north of the Cabo de Gata-Serrata de Níjar (Fig. 1b).

Both in the Campo de Dalías and Almería-Níjar Basin, the Pliocene deposits can be divided into two unconformable units. The lower one (the subject of this study) consists of marls, silts, sands, conglomerates, and calcarenites-calcirudites. This unit ranges in age from the early Pliocene in the lower part to the early middle Pliocene at the top (Aguirre, 1998). The upper unit crops out only locally in the Campo de Dalías but extensively in the Almería-Níjar Basin and is mostly composed of silts, sands, and conglomerates. In the Almería-Níjar Basin, these terrigenous deposits intercalate bioconstructions formed by the scleractinian coral Cladocora caespitosa Linne 1776 (Aguirre \& Jiménez, 1997, 1998; Aguirre, 1998).

In the Carboneras Basin, the Pliocene sediments are represented only by the lower unit, which consists mostly of calcarenites-calcirudites with sands and conglomerates in the upper part (Aguirre, 1998; Braga et al., 2003a; Martín et al., 2004).

The stratigraphy, facies analysis and interpretation, taphonomy of marine invertebrate fossil assemblages, and the palaeogeographic context of the lower Pliocene deposits in the selected areas have been studied elsewhere (Montenat et al., 1990; Boorsma, 1992; Aguirre et al., 1996, 2002; Aguirre, 1996, 1998; Braga et al., 2003a, 2003b, 2006; Martín et al., 2003, 2004). Therefore, in this study we focus on the taxonomy of the pectinid species.

Figure 1. Geological maps of the Campo de Dalías area, Almería-Níjar Basin, and Carboneras Basin with indication of the sampled localities (modified from Aguirre, 1998). a, Campo de Dalías area: 1.- Balanegra; 2.- Balerma; 3.- Matagorda-El Sabinar. b, Almería-Níjar and Carboneras Basins: 1.- Pechina; 2.- Polígono Industrial; 3.- Palmo de Salas; 4.- Los Juanorros; 5 .Cuevas de los Medinas; 6.- Lomillas de Juan Úbeda; 7.- Rambla de la Sepultura; 8.- Rambla Quebrada; 9.- El ArgamasónLos Ranchos; 10.- El Barranquete; 11.- Carboneras. 

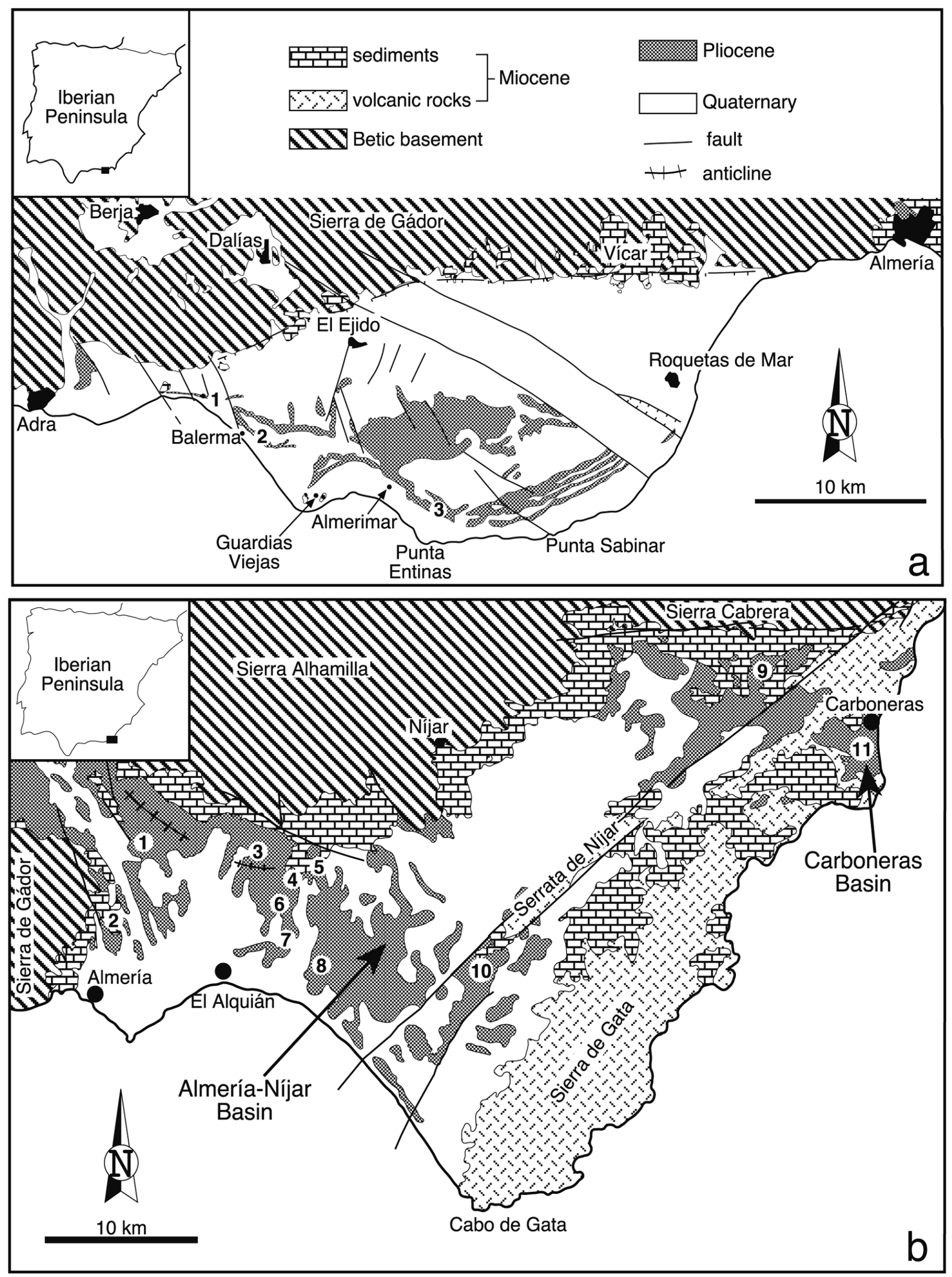


\section{MATERIALS AND METHODS}

The taxonomy of pectinids of the lower unit in the Campo de Dalías, Almería-Níjar Basin, and Carboneras Basin has been carried out. Sampling was performed in several selected sections (Fig. 1). Individual specimens were dug out from the bulk sediment along the sections. The number of specimens of identified species differs depending on preservation stage, relative scarcity, and collection difficulties. All the collected material is housed in the Departamento Estratigrafía y Paleontología, at the Universidad de Granada (Spain).

Supraspecific taxonomy of members included within the family Pectinidae is under discussion at present. Phylogenetic classification schemes of the family based on anatomical features, including shell microstructure (Waller, 1991, 1993, 2006a, 2006b), and on molecular analyses (Matsumoto \& Hayami, 2000; Barucca et al., 2004; Saavedra \& Peña, 2006) have been proposed. We follow the subdivision into four subfamilies of the family Pectinidae proposed by Waller (2006a): Camptonectinae, Pectininae, Chlamydinae, and Palliolinae. This subdivision has been corroborated by molecular phylogeny based on mitochondrial 16S and 12S ribosomal RNA genes (Saavedra \& Peña, 2006). Nevertheless, much work is still needed since: a) the subfamily Chlamydinae is paraphyletic (Waller, 2006a); and, b) the subfamily Palliolinae is not statistically separated in the maximum likelihood tree (Saavedra \& Peña, 2006: 117, fig. 2).

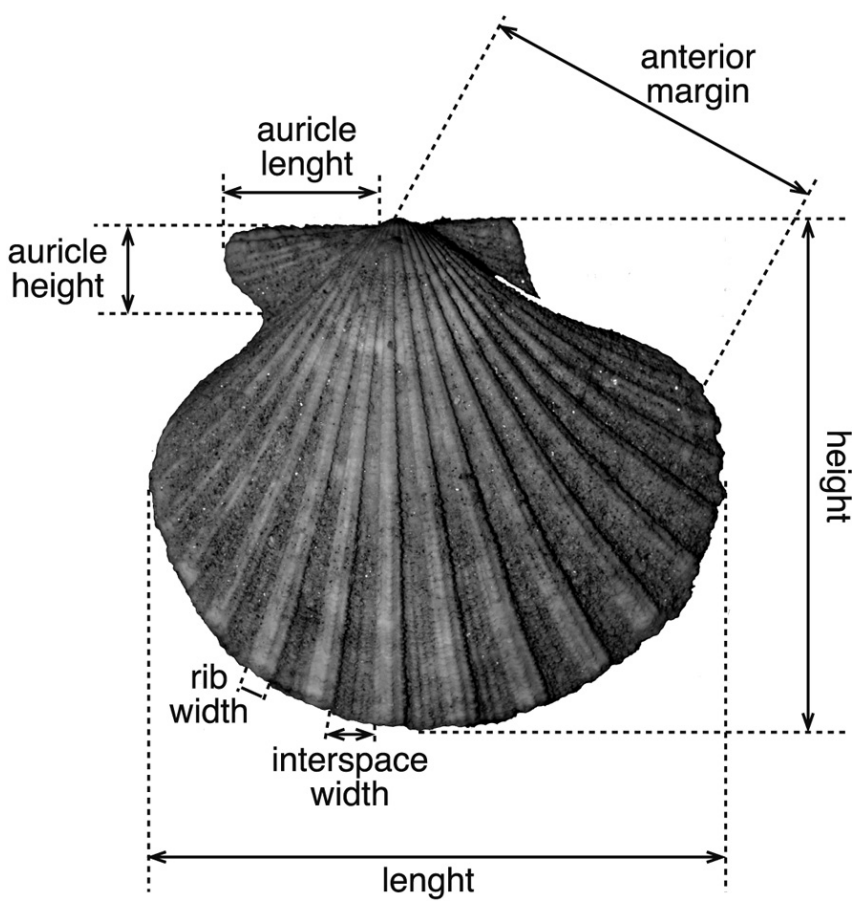

Figure 2. Some of the morphological features measured in the pectinid shells.
The same problem applies to the pectinid genera and the generic attribution of many species (Waller, 2006a, 2006b). The status of many genera is still uncertain and species are assigned to different genera depending on the authors. Nonetheless, there is certain stability in the species concept that allows adequate classification at the species levels. Moreover, some morphological features representative of the general morphology of the shells have been measured (Fig. 2). The results are provided in Table 1 and appendix 1.

\section{TAXONOMIC PALAEONTOLOGY}

\author{
Order PTERIOIDA Newell, 1965 \\ Suborder PTERIINA Newell, 1965 \\ Superfamily Pectinoidea Rafinesque, 1815 \\ Family Pectinidae Rafinesque, 1815 \\ Subfamily Chlamydinae von Teppner, 1922
}

\section{Genus Aequipecten Fisher, 1886}

Rounded outline; biconvex shell; shallow byssal notch; marked radial ribs; strong costae in the auricles; usually marked concentric growth-lines throughout the ontogeny.

\section{Aequipecten angelonii (Stefani \& Pantanelli, 1880) Figs 3a, 3b}

Material: Three complete articulated specimens and ninety-six complete but disarticulated right and left valves.

Description: Medium-large shell (Table 1), thin during juvenile stages and thicker in adults. Slightly inequilateral; anterior and posterior margins straight, the posterior one descending a bit more than the anterior. Nearly equivalve, with the left valve slightly more convex than the right one. Almost circular outline, with the height slightly greater than the length (Table 1).

External surface of both valves ornate with 17-23 radial ribs. Close to the umbo, the section of the ribs is triangular with a rounded apex and thinner than the interspaces. Each rib has tilelike scales. The section of the rib grades to triangular with an acute and sharp apex in the mid part of the shell; width is similar to the interspaces (Table 1). A groove and one secondary costa (occasionally two) occur in the flanks of the ribs that have void spines curved upright. The interspaces are ornamented only with concentric growth lines.

Auricles of the right valve are different in size and shape. The anterior auricle is larger and longer than the posterior (Table 1), with a small byssal sinus. It has 4-5 divergent costae with scales that are sometimes spiny, especially close to the cardinal margin. The posterior auricle is ornamented with thinner and fewer costae.

The anterior auricle of the left valve is larger than the posterior (Table 1). The former has 2-4 thin spiny costae. 


\begin{tabular}{|c|c|c|c|c|c|c|c|c|c|c|c|}
\hline & & \multirow[t]{2}{*}{ height } & \multirow[t]{2}{*}{ lenght } & \multirow{2}{*}{$\begin{array}{l}\text { anterior } \\
\text { margin }\end{array}$} & \multicolumn{2}{|c|}{ anterior auricle } & \multicolumn{2}{|c|}{ posterior auricle } & \multirow[t]{2}{*}{ rib width } & \multirow{2}{*}{$\begin{array}{c}\text { interspace } \\
\text { width } \\
\end{array}$} & \multirow{2}{*}{$\begin{array}{c}\text { number of } \\
\text { ribs }\end{array}$} \\
\hline & & & & & height & lenght & height & lenght & & & \\
\hline \multicolumn{12}{|l|}{ CHLAMYDINAE } \\
\hline Aequipecten angelonii & (R. V.) $(\mathrm{N}=20)$ & 49.8 & 49.6 & 25.4 & 8.7 & 15.6 & 7.7 & 10.1 & 1.6 & 1.5 & 20.1 \\
\hline & (L. V. $)(\mathrm{N}=30)$ & 54.5 & 53.4 & 28.3 & 11.2 & 15.2 & 8.8 & 10.7 & 2.01 & 2.2 & 19.7 \\
\hline A. opercularis & $($ R. V.) $(\mathrm{N}=31)$ & 37.1 & 37.3 & 19.2 & 6.2 & 11.6 & 6.8 & 8.5 & 1.4 & 1.3 & 17.5 \\
\hline & (L. V.) $(\mathrm{N}=29)$ & 39.6 & 39.6 & 24.0 & 7.1 & 10.4 & 6.5 & 8.7 & 1.4 & 1.4 & 17.2 \\
\hline A. scabrella & (R. V.) $(\mathrm{N}=30)$ & 27.1 & 28.8 & 16.3 & 4.8 & 9.1 & 6.1 & 6.7 & 1.3 & 1.2 & 13.8 \\
\hline & $($ L. V.) $(\mathrm{N}=31)$ & 27.5 & 28.9 & 16.2 & 5.7 & 8.0 & 5.6 & 6.7 & 1.2 & 1.5 & 14.4 \\
\hline Chlamys multistriata & $(\mathrm{R} . \mathrm{V}).(\mathrm{N}=7)$ & 28.6 & 24.3 & 15.7 & 6.0 & 8.7 & 4.6 & 3.8 & 0.5 & 0.6 & 29.6 \\
\hline & $($ L. V.) $(\mathrm{N}=9)$ & 31.1 & 25.3 & 15.4 & 7.9 & 9.1 & 5.4 & 4.6 & & & 32.9 \\
\hline Ch. varia & (R. V.) $(\mathrm{N}=11)$ & 47.2 & 41.9 & 24.6 & 9.2 & 14.2 & 7.8 & 8.9 & 1.2 & 1.2 & 23.0 \\
\hline & $(\mathrm{L} . \mathrm{V}).(\mathrm{N}=18)$ & 46.5 & 40.2 & 24.4 & 10.8 & 13.5 & 8.8 & 9.1 & 1.0 & 1.1 & 23.2 \\
\hline Floxopecten flexuosa & (R.V.) $(\mathrm{N}=4)$ & 26 & 27.3 & 17.8 & 6.5 & 8.5 & 6 & 8 & 3.9 & 3.1 & 4.3 \\
\hline & $($ L. V.) $(\mathrm{N}=1)$ & 21 & 19 & 15 & 5 & 8 & 5 & 7 & 1.8 & 2 & 5 \\
\hline Hinnites crispus & (R. V.) $(\mathrm{N}=1)$ & 101 & 111 & 51 & & & 5 & 21 & & & \\
\hline \multicolumn{12}{|c|}{ (L.V.) } \\
\hline H.ercolanianus & (R. V.) $(\mathrm{N}=2)$ & 58.7 & 55 & 21 & 10 & 16 & 3.5 & 10 & & & \\
\hline & $(\mathrm{L} . \mathrm{V}).(\mathrm{N}=1)$ & 54 & 51 & 18 & 5 & 6 & 7 & 6 & & & \\
\hline Manupecten pesfelis & $(\mathrm{R} . \mathrm{V}).(\mathrm{N}=1)$ & 54 & 44 & 30 & 15 & 15 & & & 6.6 & 4.8 & 5 \\
\hline & $(\mathrm{L} . \mathrm{V}).(\mathrm{N}=3)$ & 54.7 & 44.0 & 31.3 & 5.0 & 9.0 & 14.3 & 14.7 & 4.2 & 6.3 & 5.7 \\
\hline \multicolumn{12}{|l|}{ PALLIOLINAE } \\
\hline Korobkovia oblonga & (R.V.) $(\mathrm{N}=2)$ & 49 & 43.5 & 22 & 5 & 5.5 & 4.5 & 6 & & & \\
\hline & $(\mathrm{L} . \mathrm{V}).(\mathrm{N}=5)$ & 44 & 39.7 & 17.8 & 4.6 & 5 & 3.8 & 4.4 & & & \\
\hline Palliolum excisum & (R. V.) & & & & & & & & & & \\
\hline & $(\mathrm{L} . \mathrm{V}).(\mathrm{N}=2)$ & 36.5 & 38 & 18.5 & 3 & 4 & 4 & 5 & & & \\
\hline P. tigerinum & $(\mathrm{R} . \mathrm{V}).(\mathrm{N}=2)$ & 20 & 19.5 & 10 & 4 & 7.5 & 2.5 & 3 & & & \\
\hline \multicolumn{12}{|c|}{ (L. V.) } \\
\hline Pseudamussim clavatum & (R. V.) $(\mathrm{N}=31)$ & 27.6 & 26.7 & 14.6 & 4.4 & 5.6 & 4.0 & 3.6 & 5.0 & 3.0 & 3.9 \\
\hline & $($ L. V. $)(\mathrm{N}=30)$ & 25.4 & 24.0 & 14.2 & 4.2 & 5.2 & 3.2 & 3.6 & 3.5 & 4.6 & 3.1 \\
\hline \multicolumn{12}{|l|}{ PECTININAE } \\
\hline Amusium cristatum & (R. V.) (N = 23) & 62.6 & 64.9 & 25.0 & 7.7 & 11.0 & 7.6 & 10.2 & & & 26.2 \\
\hline & $(\mathrm{L} . \mathrm{V}).(\mathrm{N}=20)$ & 54.9 & 55.4 & 19.4 & 6.6 & 9.9 & 6.0 & 9.5 & & & 23.8 \\
\hline Flabellipecten alessii & (R. V.) $(\mathrm{N}=4)$ & 98.3 & 111.8 & 51.7 & 14.0 & 21.0 & 12.7 & 22.3 & & & \\
\hline & $(\mathrm{L} . \mathrm{V}).(\mathrm{N}=4)$ & 97 & 107 & 42.25 & 12.7 & 21.7 & 10.5 & 21.5 & & & \\
\hline F. bosniasckii & (R.V.) (N=7) & 81.9 & 88.7 & 49.3 & 16 & 21.5 & 13.6 & 20.9 & 3.6 & 1.8 & 22.6 \\
\hline & $(\mathrm{L} . \mathrm{V}).(\mathrm{N}=6)$ & 81.5 & 87.0 & 50.2 & 13.7 & 21.8 & 14.2 & 23.3 & 2.1 & 3.4 & 17.8 \\
\hline F. flabelliformis & (R. V.) $(\mathrm{N}=7)$ & 72.0 & 71.6 & 44.5 & 12.1 & 16.3 & 12.1 & 19.0 & 3.0 & 1.3 & 24.1 \\
\hline & (L. V.) $(\mathrm{N}=8)$ & 59 & 73.8 & 31 & 11.6 & 19 & 11 & 20.6 & 1.98 & 2.72 & 18.4 \\
\hline Gigantopecten latissimus & $(\mathrm{R} . \mathrm{V}).(\mathrm{N}=3)$ & 134.3 & 167.5 & 82.5 & & & 26.0 & 48.5 & 18.1 & 17.4 & 6.0 \\
\hline & $(\mathrm{L} . \mathrm{V}).(\mathrm{N}=2)$ & 158.5 & 166.5 & 72 & 21 & 40 & 25 & 43 & 14.6 & 12.5 & 5 \\
\hline Pecten bipartitus & $(\mathrm{R} . \mathrm{V}).(\mathrm{N}=6)$ & 50.8 & 56.0 & 30.0 & 10.5 & 13.5 & 11.6 & 14.4 & 3.6 & 2.1 & 11.7 \\
\hline & $(\mathrm{L} . \mathrm{V}).(\mathrm{N}=6)$ & 46.3 & 53.3 & 24.7 & 8.7 & 14.4 & 9.8 & 14.8 & 2.2 & 2.9 & 11.0 \\
\hline P. maximus & (R. V.) $(\mathrm{N}=29)$ & 75.6 & 85.4 & 45.9 & 12.7 & 18.6 & 13.7 & 18.5 & 5.9 & 3.6 & 12.8 \\
\hline & (L.V.) $(\mathrm{N}=21)$ & 57.1 & 70.5 & 31.0 & 10.6 & 17.2 & 12.1 & 18.1 & 3.4 & 4.9 & 11.8 \\
\hline P.planariae & $($ R.V. $)(\mathrm{N}=3)$ & 100.3 & 114.0 & 61.0 & 21.0 & 29.0 & 19.0 & 26.0 & 7.6 & 4.1 & 12.3 \\
\hline & (L. V.) (N = 3) & 88 & 110 & 45.5 & 14.7 & 24.7 & 15 & 15 & 5 & 6.1 & 11 \\
\hline P. westendorpianus & $($ R. V.) $(\mathrm{N}=3)$ & 48 & 52.7 & 20 & 9 & 10.5 & 10 & 12 & 6.5 & 1.9 & 7.3 \\
\hline & $($ L. V.) $(\mathrm{N}=1)$ & & & & 8 & 15 & & & & & 8 \\
\hline
\end{tabular}

Table 1. Average values of the morphologic features referred to in figure 2 of the pectinid species. All figures are in millimetres. R. V. = Right valve; L. V. = Left valve; $\mathrm{N}=$ number of specimens (the raw data are shown in the appendix). 

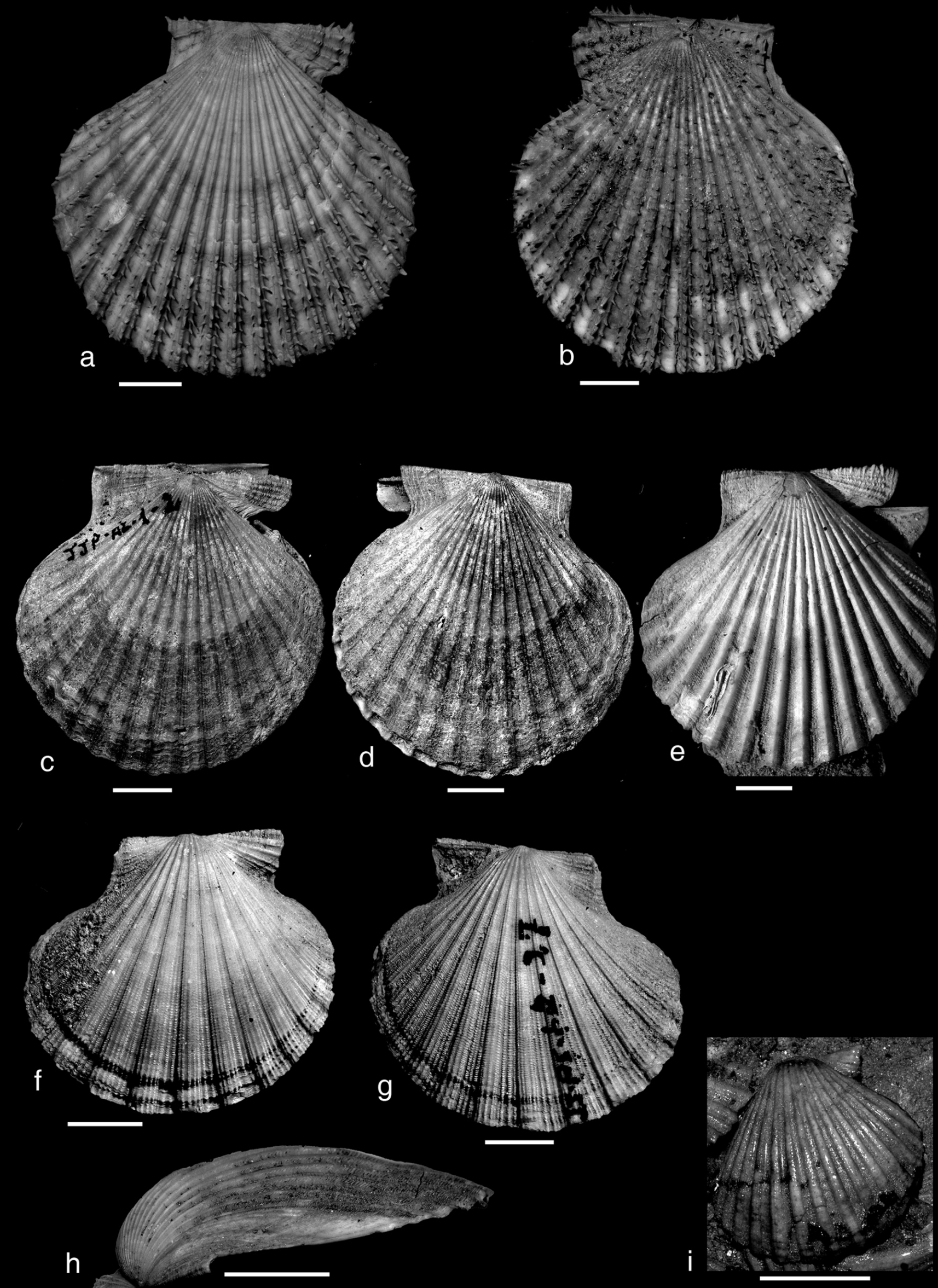
Remarks: A. angelonii is similar to A. opercularis (Linne, 1758) during juvenile stages. In adulthood, they differ since the shell of $A$. angelonii is thicker, the auricles are different, the radial ribs have a very characteristic triangular section, and it has spines.

Localities and facies: This species is especially abundant in marls, silts, and fine-grained sands in the outcrops of the Poniente Almeriense area, between Matagorda and Almerimar.

\section{Aequipecten opercularis (Linne, 1758)}

Figs $3 \mathrm{c}, 3 \mathrm{~d}, 3 \mathrm{e}$

Material: Three complete articulated individuals, and sixty-one complete valves, including right and left valves.

Description: Shell of medium size, thin and nearly circular in outline (Table 1). Nearly equivalve, with the left valve slightly more concave than the right one. The umbo is curved in the left valve. Equilateral to inequilateral.

External ornamentation consisting of 14-21 radial ribs. The shape of the rib section is different in the valves and changes from the dorsal to the ventral margin. In the left valve, the ribs are triangular in section with a rounded apex and thinner than the interspaces close to the umbo; in the ventral margin, ribs are acute triangular or rounded in section and with the same width than the interspaces (Table 1). In the right valve, the ribs are rounded to quadrangular in section and thinner than the interspaces close to the umbo, but triangular to rounded with the same width than the interspaces in the ventral margin (Table 1).

Specimens with triangular ribs have 3-6 secondary radial costae on the ribs, the one in the apex of the triangular rib being wider than the others, and 3 costae in the interspaces. All these secondary costae are densely covered by imbricate tilelike scales.

Specimens with rounded radial ribs possess 6-8 secondary costae on the ribs and 3 in the interspaces that are also densely covered by tile-like scales. The high density of the scales gives a cord-like appearance to the interspaces. Both the ribs and the interspaces may have one or two more pronounced costae, not necessarily coinciding with those in the middle part.

The auricles of the right valve are different. The anterior auricle, with a shallow byssal sinus, is larger than the posterior one (Table 1), which is triangular in shape. Both auricles have 6-8 radial ribs, thicker and ornamented with small knobs in the anterior auricle. In the left valve, the anterior auricle has the same number of ribs as the anterior auricle of the right valve. The posterior auricle, however, has fewer ribs.

Remarks: This species is similar to A. scabrella (Lamarck, 1819), but they differ since A. opercularis has a less curved umbo and the outline is circular and more regular than $A$. scabrella, which is very asymmetric (the anterior-posterior diameter is larger than the dorsal-ventral one) (Figs 3f, 3g).

A. opercularis shows significant morphologic variability. In this respect, Aequipecten zenonis Cowper-Reed, 1935 is considered to be a morphotype of A. opercularis based on the similar convexity of the shell and the external ornamentation (Fig. 3e).

Localities and facies: Aequipecten opercularis is very abundant and common in the Pliocene deposits of Almería, usually found in all the study sections. This species is especially abundant in facies of calcarenites-calcirudites, medium- to fine-grained sands, and silts.

\section{Aequipecten scabrella (Lamarck, 1819) Figs 3f, 3g, 3h, 3i, 4a, 4b}

Material: Fourteen articulated complete individuals, hundreds of complete isolated valves, both right and left, and numerous fragments.

Description: Small to medium shell (Table 1). Triangular-ovoidal outline. Inequivalve; right valve is more concave than the left one but in some specimens the difference in concavity is very subtle. The maximum concavity is close to the umbo. Shell inequilateral, the posterior margin is slightly more concave and larger than the anterior one. In all these samples, height is less than the length (Table 1).

The external surface of both valves has 12-17 radial ribs that are thinner than the interspaces or of similar width. The ribs are quadrangular to round in section close to the umbo but rounded in the ventral margin, where the interspaces are more concave. The change from quadrangular to rounded section of the ribs takes place in the first third part of the height of the valve. Nonetheless, some adult individuals have ribs that are quadrangular in section during ontogeny.

In the juvenile stages, secondary ornamentation consists of concentric lamellae that start out horizontal and then incline towards the ventral margin on the dorsal side of the rib. A very thin costa, parallel to both flanks of the rib, forms as a consequence of the intersection between the concentric lamellae and the base of the rib. As the shell grows, and coinciding with the morphological change of the rib section, the lamellae give way to scales arranged in lines originating costae with scales separated by grooves. The number of costae in the ventral region varies from 3 to 6 on the radial ribs and from 1 to 4 in the interspaces.

The cardinal margin in the right valve is prominent. The anterior auricle in this valve is enlarged and thinner than the posterior one (Table 1), and has a small, triangular byssal sinus. Both the anterior and the posterior auricles have radial costae cross-cut by growth lines, giving way to spiny scales. The cardinal margin in the left valve is straight, slightly prominent on the umbo. The auricles of the left valve have thinner, more numerous cos-

Figure 3. a-b, Aequipecten angelonii (Stephani \& Pantanelli, 1880) right valve (a) and left valve (b); c-e, Aequipecten opercularis (Linne, 1758) right valve (c), left valve (d), and right valve of A. opercularis type A. zenonis Cowper-Reed, 1935 (e); f-i, Aequipecten scabrella (Lamarck, 1819) right valve (f), left valve (g), small micro-sculpture transverse to the lateral margin in A. scabrella (h), and right valve of A. scabrella type bollenensis Mayer, 1876 (i). Scale bars $=1 \mathrm{~cm}$. 

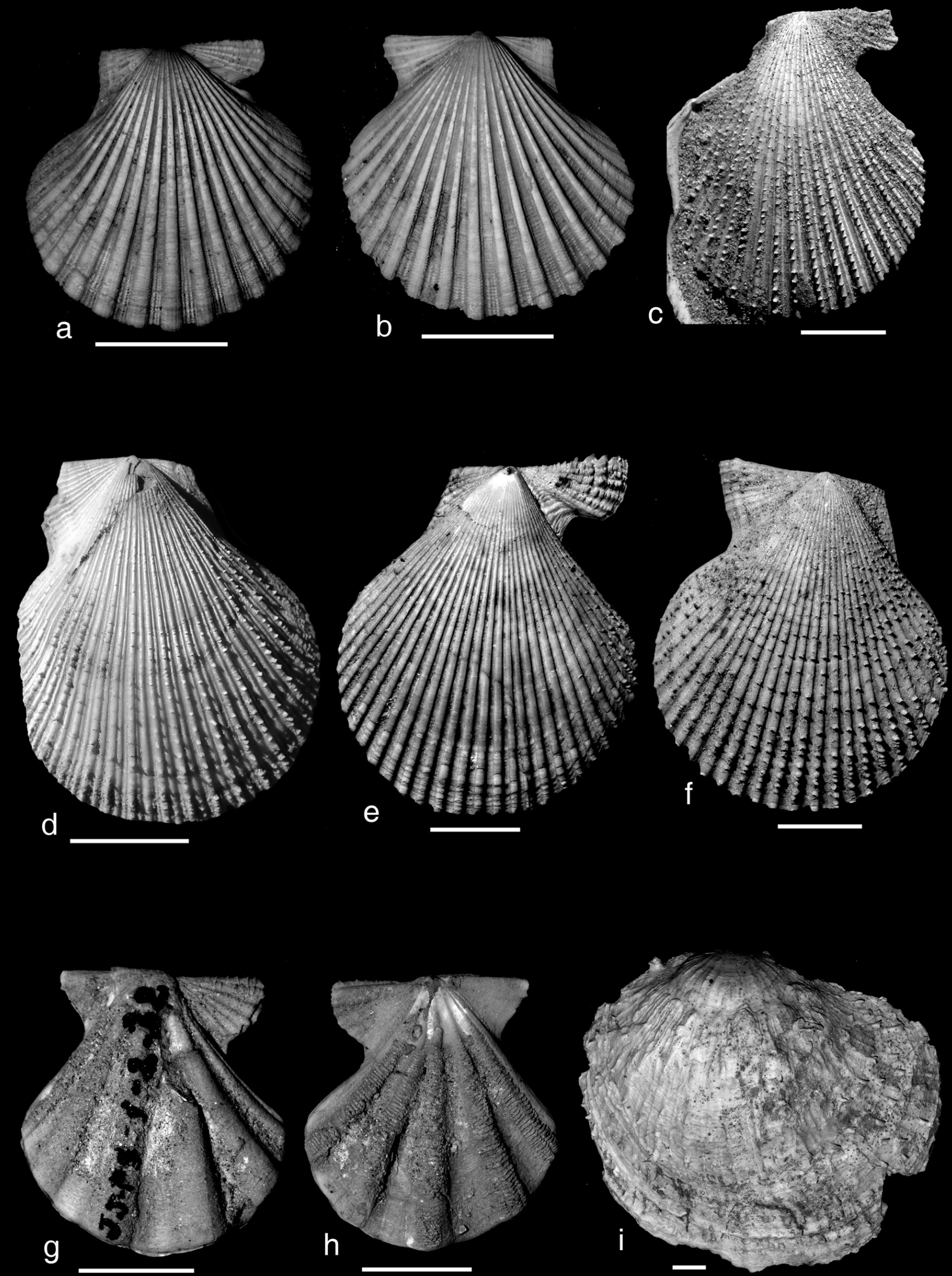
tae than those in the right valve. Imbricate, tile-like scales form in the intersection between the costae and the growth lines.

Many adult individuals of $A$. scabrella show characteristic micro-ornamentation (observable with hand lens) in the lateral margins of the shell consisting of small scales transverse to the margins.

Remarks: A. scabrella shows great morphological variability and, therefore, some species could be considered synonyms. Roger (1939) described micro-ornamentations along the cardinal margin as characteristic of Aequipecten radians (Nyst \& Westendrop, 1839) (Figs 4a, 4b). However, the same ornamental trait has been observed in adult individuals of A. scabrella (Fig. 3h) and it is not unique to $A$. radians. Furthermore, the external ornamentation and the convexity of the valves of $A$. radians do not differ from A. scabrella. Therefore, A. scabrella can be considered as a younger synonym of $A$. radians.

Aequipecten seniensis was described by Lamarck (1819) in the same publication as A. scabrella, but they are indistinguishable from each other. According to the priority of publication, A. seniensis has priority. Nevertheless, A. scabrella is the most widely used species name among authors, thus we prefer to maintain this species name.

Aequipecten bollenensis Mayer, 1876 (Fig. 3i) is also considered to be co-specific with A. scabrella since the two species show similar morphological features.

Localities and facies: This is one of the most common species in these deposits, occurring in all the sections sampled. It is also commonly found in all the different lithologies. Therefore, it is inferred that A. scabrella is a very generalist species.

\section{Genus Chlamys Röding, 1798}

Biconvex shell; inequilateral (asymmetrical) and inequivalve (left valve usually more convex than the right one); anterior auricle larger than the posterior one; deep byssal notch; external ornamentation mostly consisting of radial ribs intersected by comarginal growth lines.

\section{Chlamys multistriata (Poli, 1795)} Figs 4c, 4d

Material: Five articulated complete individuals, two right valves, four left valves, and numerous fragments.

Description: Shell of small size, oval in shape, larger in height than in length (Table 1). Equivalve and nearly equilateral, ante- rior lateral margin is a bit shorter that the posterior one, which is slightly concave.

In the outer surface of both valves, there is a very variable number of thin and rounded radial ribs (22 to 42) close to the umbo. The ribs split as the individual grows, thus doubling the number of ribs in the ventral margin. Ribs and interspaces are similar in width (less than $1 \mathrm{~mm}$ ) (Table 1). Secondary ornamentation consists of thin growth striae that intersect the radial ribs, giving way to imbricate scales with an arrangement similar to tiles on a roof.

The cardinal margin is not straight, being higher in the anterior part of the shell. Auricles have 5 to 12 small costae diverging to the margins. The anterior auricle of the right valve is larger than that of the left valve (Table 1) and shows a deep byssal sinus. Moreover, it has fewer, but larger, costae and growth lamella transverse to the costae.

Remarks: Chlamys multistriata is similar to Ch. varia, but the latter is larger. Additionally, Ch. multistriata contains more radial ribs and they are irregularly divided to the ventral margin. Finally, $C h$. varia has spines, which do not occur in Ch. multistriata.

Localities and facies: This species is very common in fine- to medium-grained sands and silts in the whole study area. Chlamys multistriata is also found in calcarenites in lesser abundance.

\section{Chlamys varia (Linne, 1758) Figs 4e, 4f}

Material: Two complete articulated specimens, 9 right valves, 16 left valves, and numerous fragments.

Description: Small shell (Table 1). Nearly equivalve but not equilateral. Juvenile specimens are oval in shape, whereas adults are semicircular, larger in height than in length (Table 1). Both the anterior and posterior margins are straight; the anterior one slightly curved close to the end of the margin. The two valves show nearly the same convexity.

The external surfaces of both valves have 18 to 26 (23 on average) radial ribs rounded in section and with the same width as the interspaces (Table 1). In some cases, the ribs show a very thin groove asymmetrically placed closer to one of the margins than the other. Secondary ornamentation consists of growth striae parallel to the ventral margin. The striae intersect the ribs, producing tile-like scales or small spines in the biggest specimens. The density and size of the scales and spines vary substantially among individuals. In the anterior and posterior margins, there are very delicate striae, observable with the hand lens, arranged perpendicular to the radial ribs and oblique to the interspaces.

The cardinal margin is higher in the anterior part of the shell than in the posterior. Auricles have 5 to 7 radial costae with small scales in the largest individuals.

Figure 4. a-b, Aequipecten scabrella type radians (Nyst \& Westendrop, 1839) right valve (a) and left valve (b); c-d, Chlamys multistriata (Poli, 1798) right valve (c) and left valve (d); e-f, Chlamys varia (Linne, 1758) right valve (e) and left valve (f); g-h, Flexopecten flexuosa (Poli,1795) right valve (g) and left valve (h); i, Hinnites crispus (Brocchi, 1814) left valve. Scale bars $=1 \mathrm{~cm}$. 
Remarks: This is a very well-known and established pectinid species, but its generic attribution is controversial. Most authors include the species in the genus Chlamys, and we follow this attribution, but others place it in the genus Mimachlamys Iredale, 1929 (e.g. Saavedra \& Peña, 2006). This illustrates the taxonomic problems of some pectinid species as indicated above in the Method section.

Localities and facies: This species is one of the most abundant pectinids in the Pliocene deposits of the province. It mostly occurs in medium- to coarse-grained sands, calcarenites-calcirudites, and occasionally in conglomerates.

\section{Genus Flexopecten Sacco, 1897}

Triangular-oval outline; low inflation of the beacks of both valves; right valve slightly flatter than the left one; ornamentation on the outer surface of the valves consisting of low relieve radial ribs (plicae); ribs of the central part of the valve are wider than those on the marginal parts.

\section{Flexopecten flexuosa (Poli, 1795) Figs 4g, 4h}

Material: One articulated complete individual and three right valves.

Description: Small shell (Table 1) of triangular-oval outline. Inequivalve since the right valve is less concave than the left one, and inequilateral, with the anterior and posterior margins descending up to the middle part of the height of the shell. On average, the height is similar to the length (Table 1).

The right valve has 4-5, low (rounded plicae) radial ribs, with the four central ribs being slightly wider than the interspaces (Table 1). In some specimens, the rib shows a groove close to the dorsal margin that gradually disappears to the ventral margin. The left valve has 5 rounded ribs, with the three in the centre of the shell wider than the two in the margins. Ribs in the left valve are similar than the interspaces. Secondary ornamentation in both valves consists of densely-spaced concentric growth lines.

The cardinal margin is straight in both valves. Anterior auricle of the right valve is enlarged and longer than the posterior one (Table 1), possesses a small byssal sinus and radial costae. Small scales are produced in the intersections of the costae and the growth lines. Posterior auricle of the right valve has only radial costae. Anterior auricle of the left valve is triangular, with a sinuous margin and radial costae intersected by the growth lines. The posterior auricle of the left valve has one costa close to the cardinal margin and numerous growth lines that form small undulated costa in the intersection of the auricle with the shell.

Remarks: This species is morphologically very distinctive and easily distinguishable from other pectinid species of the Pliocene deposits of the province of Almería. It shows some similarities with Pseudamussium clavatum, but $F$. flexuosa is characteristically triangular in shape, has larger auricles, and shows ribs more pronounced and robust than in P. clavatum.
Localities and facies: F. flexuosa is very common in the lower Pliocene deposits of the Poniente Almeriense, especially in the Almerimar section. It is also found in many sectors of the Almería-Níjar Basin. This species is present in coarse-grained sediments, such as calcarenites-calcirudites and coarse-grained sands.

\section{Genus Hinnites Defrance, 1821}

As indicated by Waller (2006b: 331), "Hinnites is essentially a Chlamys that becomes permanently cemented to a hard substrate after an initial byssate stage and assumes a highly irregular form".

\section{Hinnites crispus (Brocchi, 1814)}

Fig. 4 i

Material: One right valve and one fragment.

Description: Large shell (101 $\mathrm{mm}$ in height; Table 1) with a rounded outline. Inequivalve and inequilateral. Anterior-posterior diameter larger than the dorsal-ventral diameter (Table 1).

Ornamentation on the external surface consists of up to irregular ribs with hollow spines appearing from one-third down the shell to the ventral margin. There are more spines in the posterior area of the shell. The spines often form due to 35 the intersection of the ribs with very think concentric growth lines. In the interspaces, there are 1 or 2 thin ribs.

Remarks: This species looks like an oyster, but the shell is thinner, the outline circular and slightly convex.

Localities and facies: $H$. crispus is very abundant in calcarenites-calcirudites, coarse-grained sands, and conglomerates. These sediments use to be well cemented in the study sites; therefore, digging complete specimens is difficult. It is abundant in the section of Los Juanorros and many areas of the Carboneras Basin.

\section{Hinnites ercolanianus Cocconi, 1873}

Figs 5a, 5b

Material: Two complete right valves, one complete left valve, and one fragment of each valve.

Description: Shell of medium size, nearly circular outline, inequivalve and slightly inequilateral. Larger in height than in length (Table 1). Right valve convex, and with the ventral margin slightly curved upwards. Left valve slightly domed.

External ornamentation is different in both valves. In the right valve, the ornamentation starts with a large number of thin radial ribs, some a bit thicker, that subdivides close to the umbo. This is the embryonic stage according to Roger (1939). These ribs are crossed by a few growth lines that sometimes displace the trajectory of the ribs. The end of this stage is marked by a concentric lamella that is curved upwards, forming a nearly vertical wall-like feature. The next stage of ornamentation consists 
of concentric lamellae oriented upwards. In the spaces between adjacent lamellae, the ornamentation may consist of: 1) concentric growth lines, 2) growth lines and thick radial ribs, or 3) very subtle folds. The last stage of ornamentation is characterised by numerous evenly spaced ribs thicker than those of the embryonic stage. In the interspaces, there are 1-3 thin costae with a slightly sinuous trajectory. Numerous growth lines intersect these ribs, producing reticulate ornamentation. In some cases, there are irregularly arranged lamellae that thicken, originating thick tubercles or spines.

Micro-ornamentation consisting of very short and thin braided lines covering both the ribs and the interspaces is visible under the hand lens in some specimens.

The first stage of ornamentation in the left valve consists of nearly 18 thin ribs with an acute vertex. Unequal secondary costae (2-6), some as thick as the main ribs, are intercalated in the interspaces. During the adult stage, both the main ribs and the secondary costae have flexuous trajectories cross-cut by growth lines, producing a small tubercle in the intersections and an overall nodular appearance on the shell.

Auricles are small with oblique margins. Externally, they are ornamented with very thin radial costae and growth lines. The cardinal margin is straight.

Remarks: H. ercolanianus shows similarities with $H$.crispus. However, the former species is smaller and varies in having thinner and more ribs, especially in the left valve.

Localities and facies: $H$. ercolanianus is mostly present in fine-grained sands of the Almería-Níjar Basin and in calcisiltites and fine-grained calcarenites of the Carboneras Basin.

\section{Genus Manupecten Monterosato, 1889}

Dorso-ventral elongated shell; triangular-oval outline; anterior auricle larger than the posterior one; deep byssal notch; radial ribs usually ornamented by costae and grooves; tubercles in the cardinal margin of the valve.

\section{Manupecten pesfelis (Linne, 1758)}

Figs $5 \mathrm{c}, 5 \mathrm{~d}$

Material: One right valve and three left valves.

Description: Shell of medium size, dorsal-ventral diameter larger than anterior-posterior one (Table 1), equivalve and slightly inequilateral. Triangular with rounded corners or oval outline. Anterior margin slightly concave and a bit shorter than posterior one, which is slightly convex.

External surface of both valves ornamented with 5-6 slightly arched radial ribs. Ribs in the right valve are wider in section than the interspaces, but in the left valve interspaces are wider than the ribs (Table 1). Both the ribs and the interspaces have thin secondary ribs and grooves. In the ventral margin, each radial rib has 6-9 thin grooves. The radial ribs sometimes have small, thin imbricate scales. In both the grooves and in the interspaces there is rhomboidal micro-ornamentation.
Anterior and posterior auricles differ in both shape and size. In the right valve, the anterior auricle is enlarged (Table 1), with a wide but shallow byssal sinus. The posterior auricle is smaller and triangular in shape. Both auricles have costae with small scales that give way to thick nodules in the cardinal margin. Auricles of the left valve are triangular in shape, the anterior auricle being larger than the posterior one. The external ornamentation of the auricles in the left valve is similar to that described in the auricles of the right valve.

Remarks: This species shows a typical triangular morphology that makes it quite distinctive from any other Pliocene pectinid species in the province of Almería. M. pesfelis could be comparable with F. flexuosa or Pseudamussium clavatum, since these species show also triangular outlines. Nonetheless, these latter two species are smaller and show a more pronounced rounded margin than M. pesfelis.

Localities and facies: $M$. pesfelis is relatively scarce in these deposits; it can be found in coarse-grained sands, included in proximal tempestites, and associated with the Cladocora caespitosa Linne, 1776 coral banks of the upper Pliocene unit of the Almería-Níjar Basin.

Subfamily Palliolinae Korobkov in Eberzin, 1960

\section{Genus Korobkovia Glibert \& van de Poel, 1965}

Thin shell; slightly convex; oval outline; shortened auricles relative to shell height; outer surface of the two valves smooth; low radial ribs in the inner surface of the left valve.

\section{Korobkovia oblonga (Philippi, 1844)}

$$
\text { Fig. 5e }
$$

Material: One articulated complete specimen, one right valve, four left valve, and several fragments.

Description: Delicate, thin small-medium shell (Table 1), nearly equivalve and slightly inequilateral. Irregular rounded-oval outline, larger in height than in length (Table 1). The umbo protrudes slightly on the cardinal margin.

Right valve oval in shape, slightly oblique and convex. External surface shows very fine striae (observable with the hand lens) and concentric growth lines. Small auricles with oblique margin and fine growth lines (Table 1). Cardinal margin straight. Inner surface of the valve smooth.

Left valve similar to the right one, but with numerous thin, radial ribs.

Remarks: The absence of either ornamentation or ribs in the outer surface of the valves is also observed in the species Amusium cristatum and Palliolum excisum. However, $K$. oblonga differs from A. cristatum since the former 


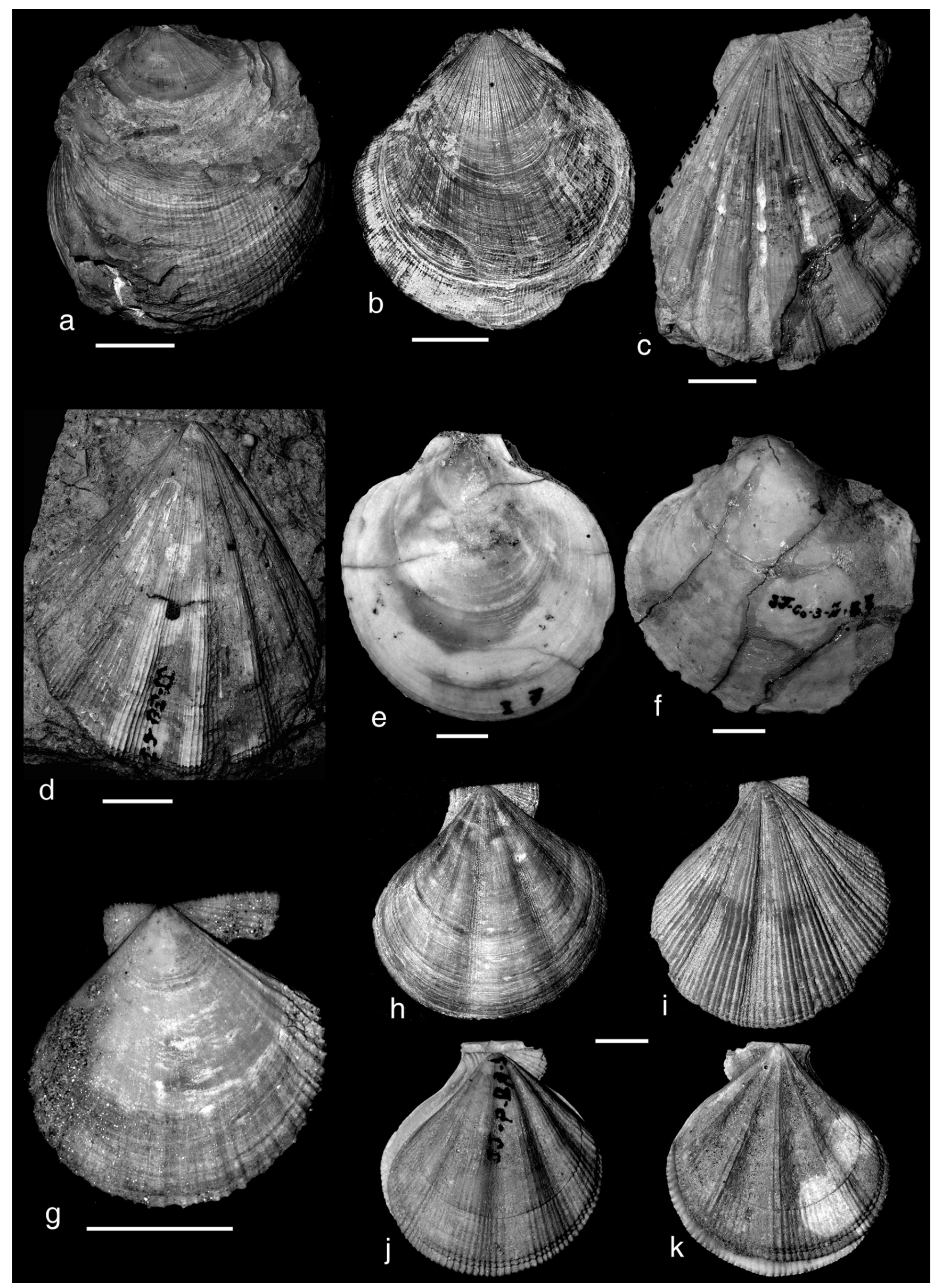


shows irregular rounded-oval morphology, is smaller and does not present ribs in the inner part of the valves. P. excisum is inequivalve, while $K$. oblonga is equivalve.

Location and facies: In the studied deposits, Korobkovia oblonga is restricted to the silts and fine-grained calcarenites of the base of the Pliocene. This species occurs in Matagorda, Los Juanorros, Cueva de los Medina, and Los Ranchos sections.

\section{Genus Palliolum Monterosato, 1884}

Triangular auricles; posterior auricles similar to the anterior ones; convex to right posterior margin of the auricles; roughly circular shells; no external ornamentation or presence of continuous and fine radial costae.

\section{Palliolum excisum (Bronn, 1831)}

Fig. $5 \mathrm{f}$

Material: Two left valves, one adult without auricles and one juvenile.

Description: Shell of medium size, larger in length than in height (Table 1). Thin, delicate shell, slightly convex and inequilateral, posterior margin slightly curved and larger than the anterior margin, which is straight. Acute umbo protrudes on a straight cardinal margin. Outer and inner surfaces of the valve smooth, with very fine growth striae.

Remarks: The valve of juvenile individuals of $P$. excisum is similar to the valve of adult specimens of $P$. tigerinum (Müller, 1776). However, they differ in general morphology and ornamentation.

Location and facies: This species is very rare in the Pliocene deposits of the province, as well as in other Pliocene sediments cropping out along the Mediterranean coast of Spain (de Porta, 1982). It has only been recorded in fine- to medium-grained sands of Los Juanorros section. Nevertheless, in the Pliocene deposits along the Atlantic coast of Andalucía (Huelva and Cádiz), P. excisum is a very common component of pectinid assemblages.

\section{Palliolum tigerinum (Müller, 1776)}

$$
\text { Fig. } 5 \mathrm{~g}
$$

Material: Two right valves, and one fragment of a left valve.

Description: Small shell of nearly equal height and length (Table 1).
Right valve thin and delicate, triangular outline, slightly convex. Outer surface shows thin radial striae (observable with hand lens) that intersect concentric fine growth lines, giving way to reticulate ornamentation. The sculpture of the outer surface shows two parts. The first part, developed during the juvenile stages, is characterised by folds and radial grooves that are irregular in width and relief. The second part is formed of folds and numerous radial grooves, which are more pronounced and irregular in width. Some of the folds have a very small groove in the centre. The anterior auricle has a byssal sinus and is larger than the posterior one. Both auricles show fine radial ribs that intersect growth lines, producing small spiny scales in the cardinal margin.

Left valve small and very delicate. The first section of the ornamentation in the outer surface has radial microstriae and some growth lines. Auricles are small, with the anterior auricle larger than the posterior one; the radial ribs are intersected by growth lines.

Remarks: The shell of this species is smaller, thinner and more delicate than P. excisum. Addtionally, $P$. tigerinum is equivalve and $P$. excisum is inequivalve.

Localities and facies: This species is very scarce in the Pliocene deposits of the province. It occurs in the silts and fine-grained sands of the Matagorda and Los Juanorros sections.

\section{Genus Pseudamussium Mörch, 1853}

Small shell in size; inequivalve, with the right valve more convex than the left one; very shallow byssal notch; ornamentation on the outer surface of the valves consisting of radial ribs of variable width; ribs ornamented with small scales; occasionally, complex microornamentation is present.

\section{Pseudamussium clavatum Poli, 1795 Figs $5 \mathrm{~h}, 5 \mathrm{i}, 5 \mathrm{j}, 5 \mathrm{k}$}

Material: One hundred and sixty valves, both right and left, and including complete shells.

Description: Shells are small, with height slightly greater than length (Table 1). Triangular outline with rounded corners. Inequivalve-the right valve is more concave than the left one. Slightly inequilateral, anterior margin slightly concave and larger than posterior margin.

Height of right valve slightly greater than width (Table 1), triangular umbo slightly protruding on the cardinal margin. Auricles are small and different in size, anterior larger than the posterior one (Table 1). Auricles have radial ribs intersected by growth striae perpendicularly oriented with the cardinal margin. Outer ornamentation of right valves consists of 3 to 5 radial

Figure 5. a-b, Hinnites ercolanianus Cocconi, 1873 right valve (a) and left valve (b); c-d, Manupecten pesfelis (Linne, 1758) right valve (c) and left valve (d); e, Korobkovia oblonga (Philippi, 1844) left valve; f, Palliolum excisum (Bronn, 1831) left valve; g, Palliolum tigerinum (Müller, 1776) right valve; h-k, Pseudamussium clavatum Poli, 1795 different morphological variants of the external ornamentation of the right valve $(\mathrm{h}-\mathrm{j})$, and left valve $(\mathrm{k})$. Scale bars $=1 \mathrm{~cm}$. 


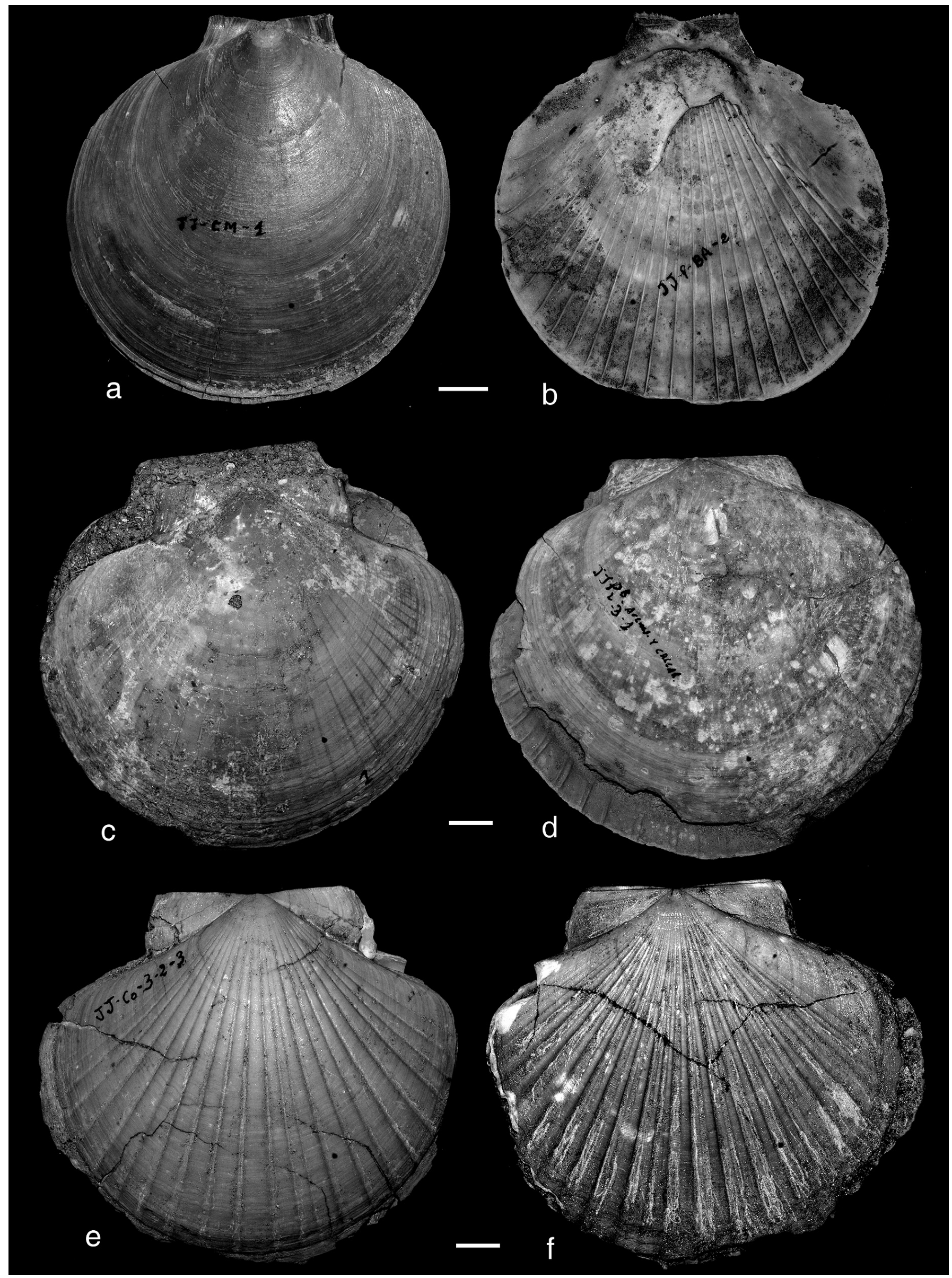


plicae. The two central plicae are wider than the rest, and they sometimes have a groove that divides the plicae into two different ribs. The outermost plicae are thin and very well defined in the proximal part but less obvious distally. Plicae are rounded in cross-section near the umbo and flatten distally, becoming wider than the interspaces (Table 1), which are concave in cross-section. Secondary ornamentation is highly variable among specimens: a) individuals with thin radial costae on the plicae and interspaces; b) nearly smooth individuals, with only very delicate striae covering the entire outer surface; and c) individuals with imbricate scales in the interspaces arranged like tiles on a roof. Finally, in both the anterior and posterior margins there are micro-striae observable with the hand lens.

Left valve similar in shape to the right valve (Table 1). Three to four plicae in the external surface, the central one being the widest. Plicae are triangular in section close to the umbo, but rounded and flattened in the ventral margin. Plicae are slightly narrower to the interspaces. Secondary ornamentation on the outer surface is similar to that observed in the right valve. Some individuals have small scales arranged like roof tiles in both the plicae and the interspaces. Like the right valve, the left valve has micro-striae in the anterior and posterior margins extending up to the auricles, as well as in the costae present in the interspaces. This sort of ornamentation is called Camptonectes-like secondary sculpture.

Remarks: Both the shape and external ornamentation are very characteristic of this species and differ from any other pectinid species found in the study area.

Localities and facies: This species is very common in the silts and fine-grained sands of the Matagorda and Los Juanorros sections.

Subfamily Pectininae Wilkes, 1810

\section{Genus Amusium Röding, 1798}

Thin and delicate shells; nearly circular in outline, almost equivalve and equilateral; both valves with low inflation; smooth outer surface of the two valves, except thin and fine growth lines; radial ribs in the inner surface of the valves; auricles of equal size without byssal notch.

\section{Amusium cristatum (Bronn, 1827)}

Figs $6 \mathrm{a}, 6 \mathrm{~b}$

Material: Twenty three right valves, twenty left valve, and numerous fragments.

Description: Shell of medium size, almost equivalve and equilateral, circular outline with the height equal or slightly less than the length of the shell (Table 1). The valves of articulated specimens are not hermetically closed but have openings in the posterior auricles (auricular gape) and in the posterior margin near the auricles (disk gape).

Right valve weakly concave, smooth and shining outer surface with very delicate growth lines. Anterior auricle similar to the posterior one. Margin of the auricles oblique, the posterior margin more inclined than the anterior one. Auricles covered with growth lines that protrude beyond the cardinal margin to produce small spines. The cardinal margin forms an obtuse angle with the umbo. The inner surface of the valve is covered by 24-28 regularly spaced radial ribs.

The left valve is similar to the right one. It is slightly convex, with a smooth outer surface with very fine growth lines. Auricles similar in size (Table 1) obliquely truncated and ornamented with growth lines. Cardinal margin straight with no spines. The inner surface of the valve has the same number of radial ribs as the right valve.

Remarks: The juvenile stages of Amusium cristatum are very similar to Korobkovia oblonga (Philippi, 1844). Notwithstanding, $K$. oblonga is smaller, with an oval outline, has smaller auricles, with no spines in the cardinal margin of the right valve, and with no ribs in the inner surface of the valves.

Localities and facies: A. cristatum is very abundant in the silts and fine-grained sands of the three study areas, especially in the Almería-Níjar Basin, where it forms dense concentrations in 5 to $10 \mathrm{~cm}$ beds, as commented in the introduction section.

\section{Genus Flabellipecten Sacco, 1897}

Biconvex shell; right valve is more convex than the left one (the latter valve nearly flat in some cases); rounded, nearly circular in outline; both anterior and posterior auricles show the same size and shape; absence of byssal notch; radial ribs of low relief.

\section{Flabellipecten alessii (Philippi, 1836) Figs $6 \mathrm{c}, 6 \mathrm{~d}$}

Material: Four complete articulated specimens and numerous fragments of disarticulated shells.

Description: Large shell (Table 1), nearly equivalve and nearly equilateral. The length of the shell is greater than the height (Table 1).

The right valve is concave, flat and shallow, with the umbo slightly deeper. Sculpture on the outer surface consists of 2530 radial very low-relieve plicae, compressed and irregular in width. Some of the plicae have a groove dividing them into two parts. Close to the anterior and posterior margins there are some

Figure 6. a-b, Amusium cristatum (Bronn, 1827) outer (a) and inner (b) surfaces of the right valve; c-d, Flabellipecten alesii (Philippi,1836) right valve (c) and left valve (d); e-f, Flabellipecten bosniasckii (Stephani \& Pantanelli, 1880) right valve (e) and left valve (f). Scale bars $=1 \mathrm{~cm}$. 

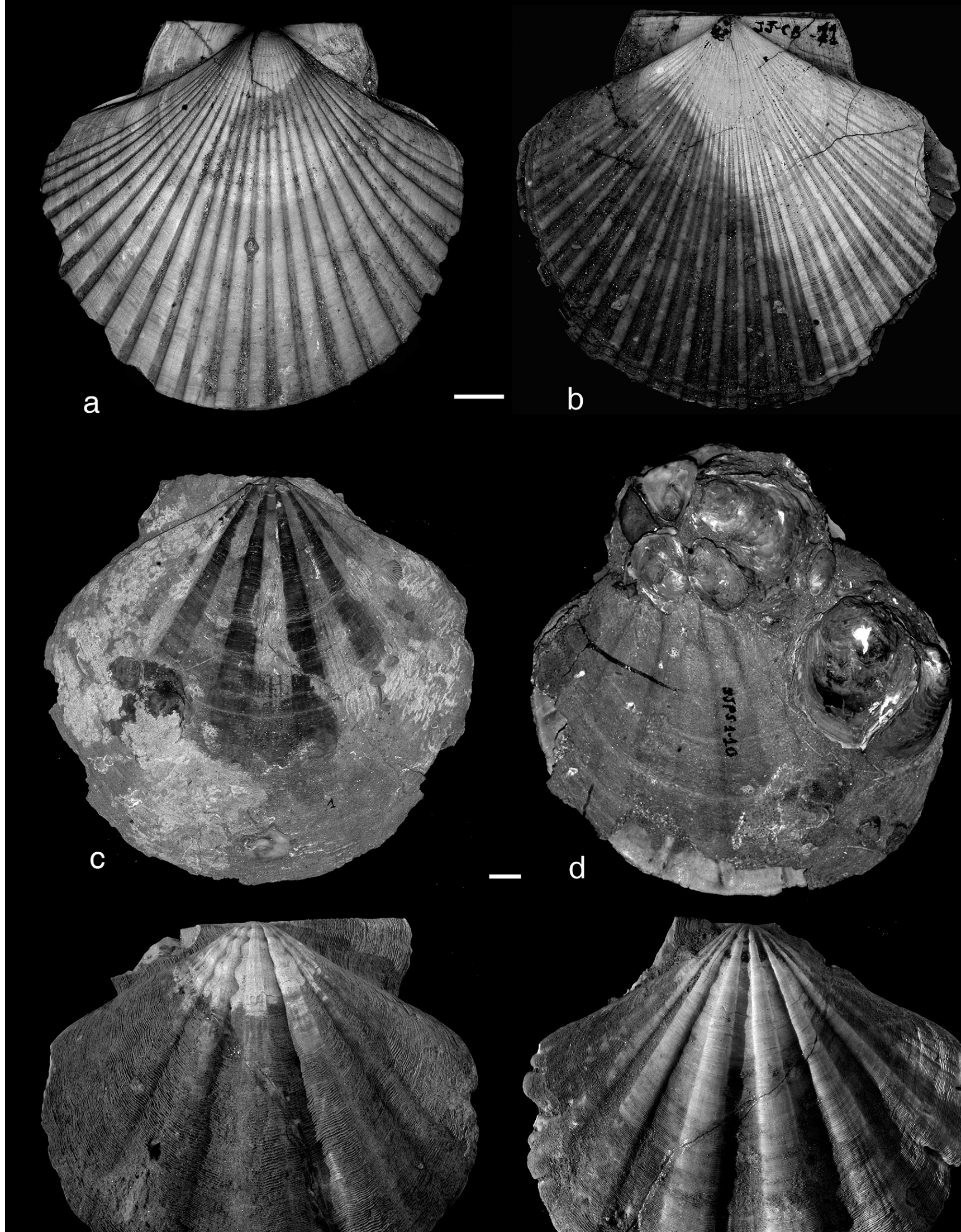

e

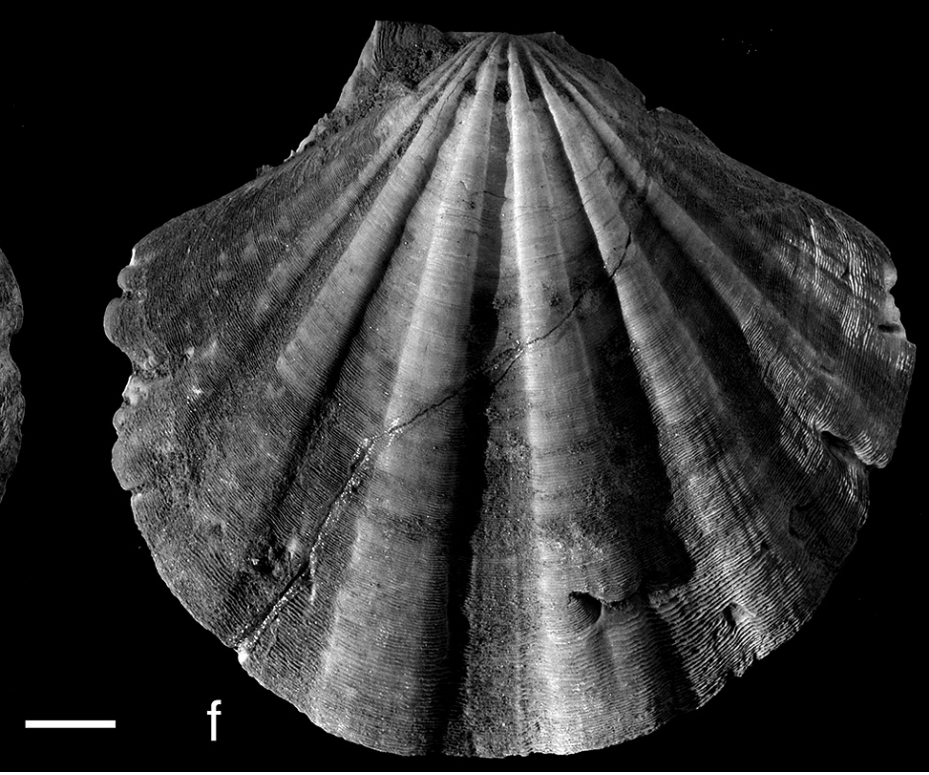


smaller secondary costae. Both the plicae and the lateral costae attenuate, nearly disappearing, towards the umbo. Secondary ornamentation consists of thin growth striae. Left valve is flat to convex, with the maximum convexity close to the centre of the valve. There is similar number of plicae flat to rounded in section. As in the right valve, there are several secondary costae close to the margins. Similarly, both the plicae and the marginal costae attenuate towards the umbo. The entire outer surface is ornamented with fine growth lines.

The anterior auricle has a shallow byssal sinus. The growth striae are arranged in bundles producing undulated plicae. Anterior and posterior auricles of the left valve are similar (Table 1) in size and show bundles of growth striae intersected by radial costae, causing a reticulation of the auricle.

Remarks: Deperet \& Román (1910) considered F. alessii to be a variety of the species F. flabelliformis (Brocchi, 1814) and described different intermediate morphologies between the two species.

Smoothed and/or abraded individuals of $F$. alessii might be similar to Amusium cristatum (Bronn, 1827) but they differ since the latter species is thinner and flatter; moreover, the only ornamentation on the outer surface of the valves is very fine growth lines.

Localities and facies: This is a relatively common species found in conglomerates and calcarenites of many localities in the study area.

\section{Flabellipecten bosniasckii (Stefani \& Pantanelli, 1880) Figs 6e, $6 f$}

Material: Seven complete articulated specimens and one complete right valves.

Description: Medium-large shell (Table 1), inequivalve and equilateral.

Right valve is convex shallow with a slightly curved umbo. The outer surface is covered by 20-27 radial ribs, quadrangular in section with rounded edges, and wider than the interspaces (Table 1), which are flat. Secondary ornamentation consists of thin growth striae more prominent in the interspaces and close to the ventral margin. The left valve is flat or slightly convex in the centre. Externally, this valve has 15-22 radial ribs that are quadrangular to rounded in section and thinner than the interspaces (Table 1). A prominent costa is visible in the centre of the interspaces. The outer surface of the left valve is covered by thin growth lines, more evident in this valve than in the right one.

Anterior and posterior auricles of the right valve are similar in size (Table 1). The anterior auricle has a small byssal sinus that extends to the umbo. Obliquely-arranged growth lines are present in both auricles of the right valve. In the left valve, the auricles are similar in size (Table 1) and have thin radial costae intersected by growth lines at a right angle.

Remarks: $F$. bosniasckii is similar to $F$. flabelliformis, but the former has fewer ribs than the latter. Additionally, the ribs of F. bosniasckii are thinner than the interspaces while the ribs of $F$. flabelliformis are usually of the same width or wider than the interspaces.

Localities and facies: This species is very common in the Pliocene deposits of this province. It occurs preferentially in medium-grained sands, conglomerates, and calcarenites.

\section{Flabellipecten flabelliformis (Brocchi, 1814) Figs $7 \mathrm{a} .7 \mathrm{~b}$}

Material: Seven complete articulated specimens, and one left valve.

Description: Shell is medium-sized, inequivalve, equilateral, and circular in outline (Table 1).

The right valve is nearly flat, slightly convex and with a very shallow umbo. The outer surface has 21-28 radial ribs quadrangular to round in section. The interspaces are thinner than the ribs (Table 1) and flat or slightly curved. Secondary ornamentation consists of concentric, thin, densely-packed growth striae. The left valve is flat and slightly convex in the central part of the valve. It has 16-22 radial ribs, quadrangular in section, in the outer surface. Close to the anterior and posterior margins are 4-5 thinner costae. The ribs display two morphologies: 1) ribs flat and wider than the interspaces and 2) ribs prominent and the same width as the interspaces or even thinner. On the external surface of the ribs, a thin costa is present, thinning towards the umbo. Prominent concentric growth striae occur throughout the outer surface of the valve.

The auricles of the right valve are large, particularly the anterior one; a byssal sinus is present at the base of the auricle. Both auricles are ornamented with transverse growth striae that converge and form small projections. The auricles of the left valve show 5-7 radial costae intersected by growth striae. The cardinal margin of the auricles is straight.

Remarks: See remarks of Flabellipecten bosniasckii.

Localities and facies: Relatively common in medium- to coarse-grained sands of the Almería-Níjar Basin.

\section{Genus Gigantopecten Rovereto, 1899}

As the name of the genus indicates, this genus is very large in size; thick shell; biconvex, although the left valve is slightly more convex than the right one; radial ribs wide

Figure 7. a-b, Flabellipecten flabelliformis (Brocchi, 1814) right valve (a) and left valve (b); c-f, Gigantopecten latissimus (Brocchi, 1814) right valve (c) and left valve (d) of an adult specimen, and right valve (e) and left valve (f) of a juvenile specimen. Scale bars $=1 \mathrm{~cm}$. 

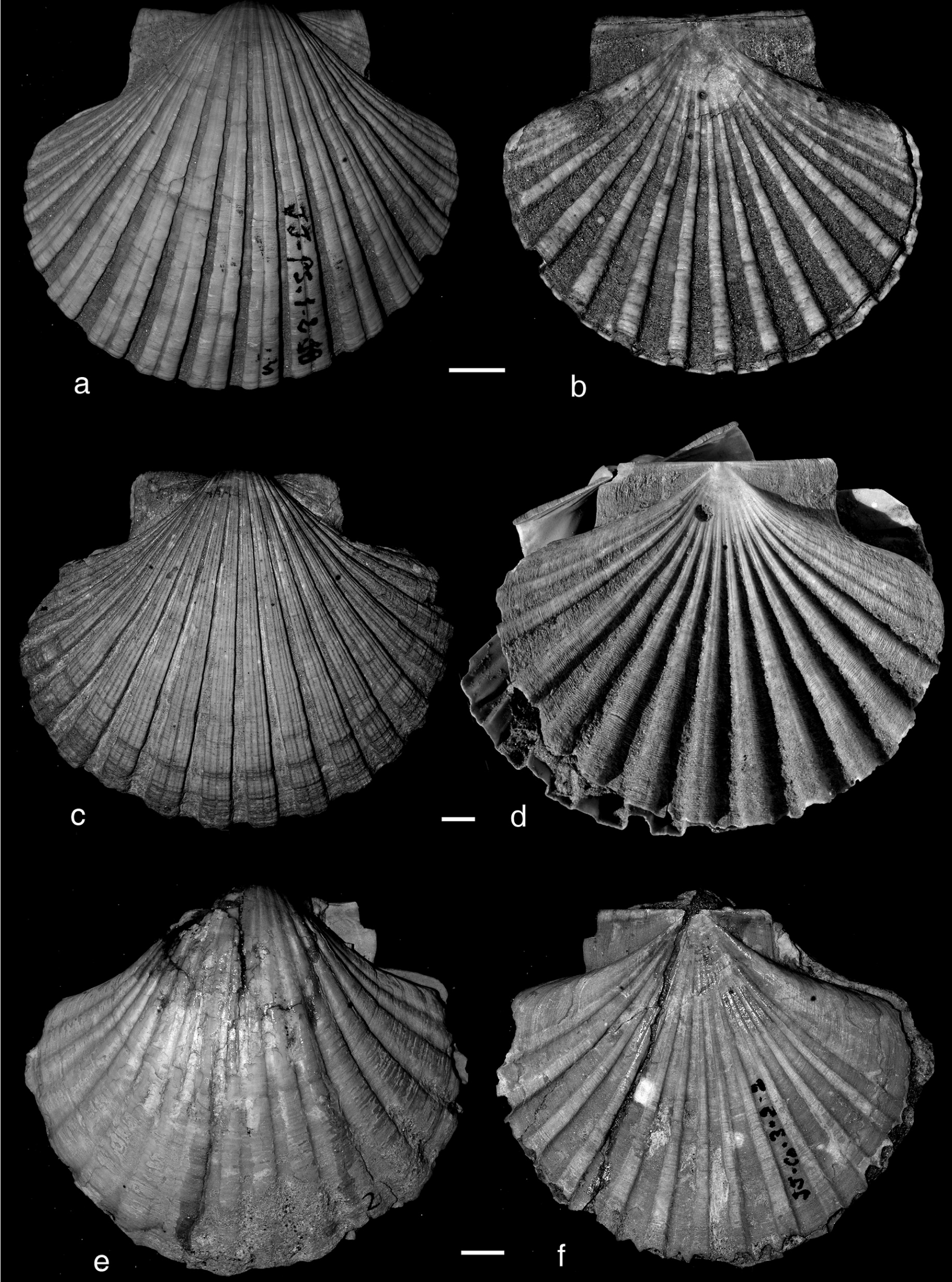
but very shallow (plicae); both anterior and posterior auricles of the same size and shape.

\section{Gigantopecten latissimus (Brocchi, 1814)} Figs 7c, 7d, 7e, $7 \mathrm{f}$

Material: Two complete articulated individuals and one right valve.

Description: Large shell (Table 1), slightly inequivalve (left valve is slightly larger and more convex than the right one) and nearly inequilateral. The dorsal-ventral diameter is smaller than the anterior-posterior one (Table 1). The anterior margin is slightly curved, whilst the posterior margin is straight and larger than the anterior one.

Right valve is shallow. The outer surface presents 6 radial ribs, rectangular in section, that thin towards the ventral margin where they look like shallow plicae. The four central ribs are wider than the rest of the ribs. Ribs are of the same width as the interspaces or slightly wider (Table 1). Shallow grooves and costae are present on part of the surface of the ribs. Interspaces show 2-6 differently marked secondary costae. The left valve is thick and slightly convex, with 5 radial ribs on the external surface. The ribs are rectangular in section with rounded corners, the three central ones being wider than the rest of the ribs. As in the right valve, the ribs flatten to the ventral margin. In some exemplars, the ribs are ornamented with 5-6 nodular structures close to the dorsal region. These nodes are aligned along the outer surface of the ribs. Both the right and the left valves show conspicuous concentric growth striae.

The auricles are badly preserved in the studied specimens. The best preserved one is the posterior auricle, which shows densely packed growth striae.

Remarks: The size and thickness of the shell, as well as the ornamentation on the outer surface, mark this species as very different from any other pectinid species of the Pliocene deposits in Almería. We have used the genus name Gigantopecten instead of Macrochlamys Sacco, 1897 (or the orthographic variant Macrochlamis Sacco, 1897) following the recommendations of Waller \& Bongrain (2006).

Localities and facies: This species is quite abundant in the study sections and mostly occurs in conglomerates, coarsegrained sands, and calcarenites-calcirudites.

\section{Genus Pecten Müller, 1776}

Right valve convex; left valve flat or slightly convex close to the umbo; auricles of the same size with no byssal notch; radial ribs with flat to outer rounded surfaces.

\section{Pecten bipartitus (Foresti, 1876)}

Figs $8 \mathrm{a}, 8 \mathrm{~b}$
Material: Six complete articulated individuals, and numerous fragments.

Description: Medium-large shell (Table 1), inequivalve and slightly inequilateral. Triangular outline with a curved ventral margin. Dorsal-ventral diameter shorter than anterior-posterior diameter (Table 1).

Right valve is convex, with a prominent umbo. External ornamentation consists of 11-13 radial ribs, quadrangular in section and wider than the interspaces (Table 1), with a groove (very occasionally two or more) in the lateral ribs. Furthermore, the outer surface of the right valve has secondary ribs: 2 in the anterior margin and 3 in the posterior one. These ribs are often ornamented with a groove. Secondary ornamentation is made up of very thin growth lamellae that intersect the ribs and interspaces. Interspaces are flat.

The left valve is flat or slightly concave close to the umbo. It possesses 11 prominent radial ribs, quadrangular in section, that thin towards the umbo. The width of the ribs is less than width of the interspaces, which are flat. The left valve also has secondary ribs, one or two in the lateral margins. Secondary ornamentation consists of very thin concentric growth lamellae, densely packed and running parallel to the ventral margin.

Auricles of medium size, with a small byssal sinus and 5-6 radial costae cross-cut by concentric growth lines.

Remarks: $P$. bipartitus could be blurred with $P$. jacobaeus Linne, 1758 because of: 1) their similar general morphology, 2) the form of the ribs, and 3) the similar secondary ornamentation. The latter is of particular concern, especially in abraded specimens of $P$. jacobaeus, in which the costae disappear and the secondary grooves fade, thus leaving only one central groove.

Localities and facies: $P$. bipartitus is found in calcirudites and medium- to coarse-grained sands in many places of the Almería-Níjar Basin and in the Poniente Almeriense area.

\section{Pecten maximus Linne, 1758}

Figs 8c, 8d

Material: Several complete articulated individuals, twenty nine complete right valves, and twenty one complete left valves.

Description: Large shell (Table 1), inequivalve and nearly equilateral, triangular-circular in outline with rounded ventral margin. Dorsal-ventral diameter is smaller than anterior-posterior one (Table 1). The difference between these two parameters is more pronounced in larger specimens.

The right valve is convex with the umbo curved and slightly prominent. This valve has 11-18 major radial ribs accompanied by 2-3 secondary narrower ribs. The number of major ribs depends on the convexity of the valve; thus, the more convex the valve, the fewer the ribs. The morphology of the rib sections changes substantially, varying from quadrangular ribs in sec-

Figure 8. a-b, Pecten bipartitus (Foresti, 1876) right valve (a) and left valve (b); c-d, Pecten maximus Linne, 1758 right valve (c) and left valve (d); e-f, Pecten planaire Simonelli, 1889 right valve (e) and left valve (f). Scale bars $=1 \mathrm{~cm}$. 
tion with sharp corners and excavated margins to rounded, lowrelief ribs. Secondary ornamentation of the right valve consists of 4-9 costae of different width separated by the same number of shallow grooves. Occasionally, the central groove is wider and deeper than adjacent ones. The interspaces are thinner than the ribs (Table 1) and flat in section. They are non-sculptured or might have thin, small costae separated by shallow grooves.

Auricles of the right valves are similar in shape (triangular) and size (Table 1). The anterior auricle often shows a small byssal sinus. They have 6-10 thin radial ribs.

The left valve is flat, with the umbo occasionally concave outwards. The external surface of the valve is ornamented with 10-16 prominent radial ribs, rounded or rectangular in section. They are thinner than the interspaces (Table 1); in some individuals, the width of the ribs is half that of the interspaces. Secondary ornamentation varies among specimens; some individuals have no trace of secondary ornamentation whereas others have small costae and grooves both in the ribs and in the interspaces.

In well-preserved specimens, conspicuous and densely arranged growth lines are observed. In the interspaces, the growth lines intersect the costae and grooves, producing very dense imbricate tile-like scales. The growth lines are often preserved only in the interspaces, since the ribs are frequently abraded.

Remarks: Pecten maximus displays significant morphological variability, both in the shape of the shell and in the morphology of the rib sections, as well as in the ornamentation of the right valve. In shape, the rib sections show two extreme morphotypes formerly attributed to two different species: 1) shells with quadrangular ribs in section, with sharp corners and with the margins slightly excavated. This morphology corresponds to the type of Pecten jacobaeus, Linne, 1758. 2) Shells with rounded and shallow ribs, corresponding to the type of Pecten maximus Linne, 1758. Recent molecular analyses of the $16 \mathrm{~S}$ ribosomal RNA genes have shown that these two species are indistinguishable and probably correspond to biogeographic varieties of the same species (Wilding et al., 1999; Saavedra \& Peña, 2005; but see Waller 2006a). Thus, populations of $P$. maximus are distributed in the Atlantic and populations of $P$. jacobaeus inhabit the Mediterranean.

$P$. maximus also shows morphological similarities with P. bipartitus (Foresti, 1876), but the latter is smaller and the ribs of the right valve have a deep groove dividing the ribs into two similar costae.

Localities and facies: $P$. maximus is a relatively common species in Almerian Pliocene deposits, found in almost all the study sites. The species occurs preferentially in calcarenites-calcirudites, coarse- and medium-grained sands, and conglomerates.

\section{Pecten planariae Simonelli, 1889}

Figs 8e, 8f

Material: Three complete articulated individuals.

Description: Large shell (Table 1), inequivalve and nearly equilateral. Length is larger than the height (Table 1). Right valve is large, convex and ornamented with 12-13 radial ribs having

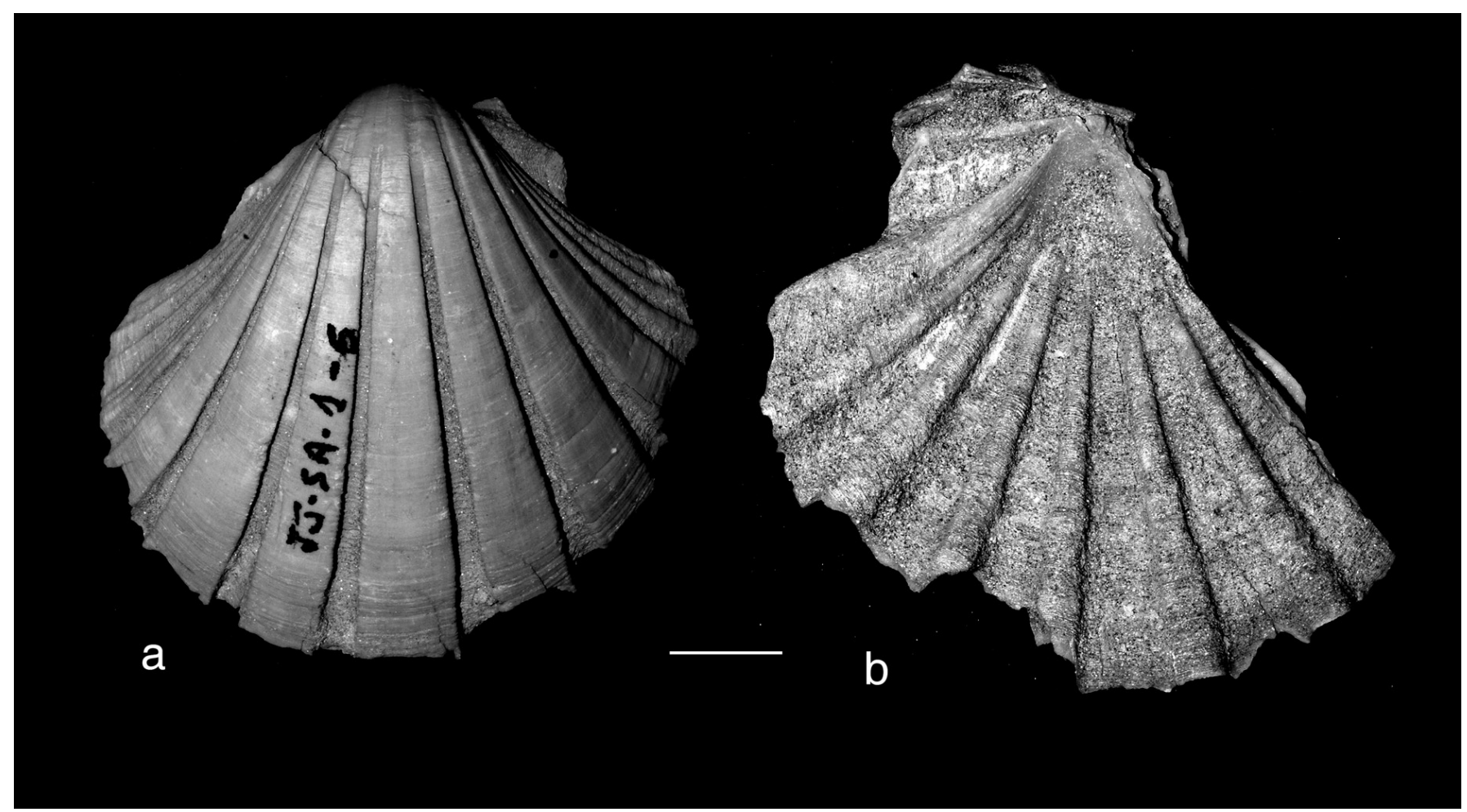

Figure 9. Pecten westendorpianus Nyst \& Westendorp, 1839 right valve (a) and left valve (b). Scale bar $=1 \mathrm{~cm}$. 
a quadrangular section with rounded edges. They are twice the width of the interspaces (Table 1) and widen in the ventral margin. Secondary ornamentation consists of thin concentric growth striae parallel to the ventral margin and more evident close to the ventral margin. Left valve is slightly concave, with 11 radial ribs quadrangular and flattened in section. The width of the ribs is less than the width of the interspaces (Table 1). The central ribs attenuate close to the umbo. Secondary ornamentation of the left valves consists of concentric growth lines, more evident close to the ventral margin.

Auricles of the right valve are big and show densely-arranged thin growth striae. Auricles of the left valves are big, with 3-4 radial costae close to the cardinal margin and cross-cut by densely-arranged, concentric thin growth striae.

Remarks: Individuals of $P$. planariae with rectangular ribs in section and rounded edges, and ornamented with 2-3 grooves are similar to the morphotype of Pecten benedictus Lamarck, 1819 with furrowed ribs illustrated by Deperet \& Román (1902). P. planariae also shows similarities with the forms attributed to $P$. maximus, but they differ in the grooves and the secondary ornamentation.

Localities and facies: $P$. planariae is found in sands and silts. All the studied material was collected in Los Juanorros section, northern margin of the Almería-Níjar Basin.

\section{Pecten westendorpianus Nyst \& Westendorp, 1839 \\ Figs $9 \mathrm{a}, 9 \mathrm{~b}$}

Material: One complete left valve, and three complete right valves.

Description: Shell of medium size, inequivalve and nearly equilateral. Dorsal-ventral diameter slightly smaller than anteriorposterior diameter (Table 1).

Right valve concave, with a deep and pronounced umbo. Outer surface showing 7-8 prominent radial ribs, rectangular in section, that widen towards the ventral margin. They are nearly three times the width of the interspaces (Table 1). Close to the anterior and posterior margins, there are 2-3 smaller secondary ribs. Both the major and the secondary ribs display 6-10 secondary costae separated by grooves of different width and depth. Fine growth striae, concentric to the ventral margin, are visible both in the ribs and in the interspaces. Left valve is flat or slightly concave, with the maximum concavity close to the umbo. This valve shows 8 radial ribs that attenuate towards the umbo (although preservation precludes measurements). They are rectangular in section with rounded edges. The interspaces are approximately three times the width of the ribs. Both the ribs and the interspaces show 2-3 thin costae and thin concentric growth striae.

Auricles of the right valve are of medium size. They are ornamented with thin radial costae and have a very small byssal sinus. Both the anterior and posterior auricles have thin growth striae, obliquely-arranged to the margin. Anterior and posterior auricles of the left valve are similar in size and have very thin oblique growth striae.
Remarks: This species is similar to $P$. maximus, but the former differs from the latter in the smaller size, the convexity of the right valve, and in having wider and fewer ribs.

Localities and facies: Pecten westendorpianus has only been found in silts in Los Juanorros section.

\section{CONCLUDING REMARKS}

Pectinids are quite significant and abundant components in the fossil assemblages of the Almería Pliocene deposits (SE Spain). They occur as the major constituents of factory facies mostly in inner-middle shelf settings (Martín et al., 2004; Braga et al., 2006) and concentrate in storm deposits along the platform (Aguirre et al., 1996; Aguirre, 1998; Martín et al., 2004; Braga et al., 2006). The explanations for the biological accumulations formed by Amusium cristatum in the Almería-Níjar Basin are not fully and satisfactorily resolved yet. The particular palaeogeographic configuration of the basin during the Early Pliocene (a protected embayment widely connected with the open sea) and a possible gregarious behaviour of the species (for instance, for reproduction and/or offspring) may account for these biological concentrations.

Although the relevance of the pectinids for interpreting facies and palaeoenvironmental conditions in the Pliocene deposits of the province of Almería has been highlighted in the aforementioned papers, no taxonomic study of pectinid species of these deposits has been carried out ever since the preliminary study by Méndez-Cecilia (1971). Here, we have described in detail the pectinid species and updated the taxonomy in the light of the new phylogeny proposed for the family.

We have recognized 22 species included in 12 genera (Aequipecten, Amusium, Chlamys, Flabellipecten, Flexopecten, Gigantopecten, Hinnites, Korobkovia, Manupecten, Palliolum, Pecten, and Pseudamussium) and 3 subfamilies (Chalmydinae, Palliolinae, and Pectininae). This number of species is higher than previously reported in the study area by Méndez-Cecilia (1971). She identified 16 species and 3 varieties, one a new variety, Chlamys clavata var. almeriense Méndez-Cecilia (1971). We have identified all the species described by Méndez-Cecilia (1971), except for Pecten benedictus, Chlamys clavata Poli, 1795 (and the varieties Ch. clavata var. estheris Crema, 1903 and Ch. clavata var. almeriense), and Ch. aff. fasciculata Millet, 1854. Additionally, some of the species reported by this author can likely be considered as synonyms of other species discussed in this paper: a) Chlamys bollenensis Mayer, 1876 and Ch.radians (Nyst \& Westendrop, 1839) might be considered synonyms of Aequipecten scabrella (Lamarck,1819) and b) Ch. zenonis Cowper-Reed, 1935) is most likely a synonym of A. opercularis (Linne, 1758). 


\section{ACKNOWLEDGEMENTS}

We are indebted with Drs Rosa Domènech and Ana Márquez, reviewers of the first version of the manuscript, for their comments and suggestions that have improved the quality of the paper. We also appreciate the editorial annotations made by Dr. Rodolfo Gozalo, editor of Revista Española de Paleontología. This paper is part of the research projects CGL2007-60774, funded by the Ministerio de Educación y Ciencia of Spain, and RNM 0190, funded by the Junta de Andalucía. We would like to thank Christine Laurin for improvements to the English text.

\section{REFERENCES}

Aguirre, J. 1996. Modelo de tafofacies en el Plioceno inferior de la cuenca de Almería-Níjar (SE de España). In: Tafonomía y fosilización (Eds. G. Meléndez Hevia, M. F. Blasco Sancho \& I. Pérez Urresti). Institución Fernando el Católico, C.S.I.C., Zaragoza, 11-18.

Aguirre, J. 1998. El Plioceno del SE de la Península Ibérica (Provincia de Almería). Síntesis estratigráfica, sedimentaria, bioestratigráfica y paleogeográfica. Revista de la Sociedad Geológica de España, 11, 297-315.

Aguirre, J. \& Jiménez, A. P. 1997. Census assemblages in hard-bottom coastal communities: a case study from the Plio-Pleistocene Mediterranean. Palaios, 12, 598-608.

Aguirre, J. \& Jiménez, A. P. 1998. Fossil analogues of the present-day ahermatypic Cladocora caespitosa coral banks: Sedimentary setting, dwelling community, and taphonomy (Late Pliocene, W Mediterranean). Coral Reefs, 17, 203-213.

Aguirre, J., Braga, J. C., Jiménez, A. P. \& Rivas, P. 1996. Substrate-related changes in pectinid fossil assemblages. Palaeogeography, Palaeoclimatology, Palaeoecology, 126, 291-308.

Aguirre, J., Márquez-Crespo, R., Pérez-Muñoz, A. B., Sánchez-Almazo, I. M. \& Yesares-García, J. 2002. Síntesis paleontológica del Plioceno inferior de la cuenca de Almería-Níjar (SE de España). Pliocénica, 2, 8-30.

Barucca, M., Olmo, E., Schiaparelli, S. \& Canapa, A. 2004. Molecular phylogeny of the family Pectinidae (Mollusca: Bivalvia) based on mitochondrial $16 \mathrm{~S}$ and $12 \mathrm{~S}$ rRNA genes. Molecular Phylogenetics and Evolution, 31, 89-95.

Boorsma, L. J. 1992. Syn-tectonic sedimentation in a Neogene strike-slip basin containing a stacked Gilbert-type delta (SE Spain). Sedimentary Geology, 81, 105-123

Braga, J. C., Betzler, C., Martín, J. M. \& Aguirre, J. 2003a. Spit-platform temperate carbonates: the origin of landward-downlapping beds along a basin margin (lower Pliocene, Carboneras basin, SE Spain). Sedimentology, 50, 553-563.

Braga, J. C., Martín, J. M. \& Quesada, C. 2003b. Patterns and average rates of late Neogene-Recent uplift of the Betic Cordillera, SE Spain. Geomorphology, 50, 3-26.

Braga, J. C., Martín, J. M., Betzler, C. \& Aguirre, J. 2006. Models of cool-water carbonate deposition in Neogene basins in SE Spain. In: Cool-water carbonates: Deposi- tional systems and palaeoenvironmental control (Eds. H. M. Pedley \& G. Carannante). The Geological Society of London, Special Publication, 255, 121-135.

Brocchi, G. 1814. Conchilogia fossile subappennina con osservazioni geologiche sugli Apennini e sul suolo adiacente, II. Stemperia Reale, Milan, 241-712.

Bronn, H. G. 1827. Ergebnisse meiner naturhistorisch-ökonomi-. schen Reisen. 1, Briefe aus der Schweiz, Italien und Südfrankreich. Im Sommer 1824, XX+654 pp. (non vide).

Bronn, H. G. 1831. Italiens Tertiär-Gebilde und deren organische einschlüsse. Heidelberg, K. Groos (non vide).

Cocconi, G. 1873. Enumerazione sistematica dei Molluschi mioceni e plioceni delle province di Parma e Piacenza. Memerie Accademie Science Istitute Bologna, s. 3, III, 742 pp.

Cowper-Reed, 1935. Notes on the Neogene fauna of Cyprus, III: The Pliocan. Annales and Magazine of Natural History, 10, XV (non vide).

De Porta, J. 1982. Distribución geográfica y cronoestratigráfica de Palliolum (Lissochlamys) excisum (Mollusca, Pectinidae) en España. Acta Geológica Hispánica, 14, 370-374.

Defrance, M. J. L. 1821. Dictionnaire des sciences naturelles par plusieurs professeurs du Jardin du Roi et des principales Écoles de Paris, Vol 31. Paris and Strasbourg (non vide).

Demarq, G. 1990. Les faunes de pectinidés du Néogène Bétique. In: Les bassins Néogènes du domaine Bétique oriental (Espagne): Tectonique et sédimentation dans un couloir de décrochement. Première partie. Étude régionale (Ed. C. Montenat). Documents et Travaux Institut Geologique Albert-de-Lapparent, 12-13, 45-48.

Depéret, Ch. \& Roman, F. 1902. Monographie des pectinidés néogénes de l'Europe et des régions voisines. Première partie. Genre Pecten. Mémoires de la Société Géologique de France, Paléontologie, 10, 1-74.

Depéret, Ch. \& Roman, F. 1910. Monographie des pectinidés néogénes de l'Europe et des régions voisines. II. Genre Flabellipecten Sacco, 1897. Mémoires de la Société Géologique de France, Paléontologie, 18, 105-139.

Eberzin, A. G. 1960. Mollyuski - pantsirnye, dvustvorchatye, lopatonogie. In: Osnovy Paleontologii (Ed. A.Yu). USSR Academy of Science, Moscow, 1-300.

Fisher, P. H. 1886 (1880-1887). Manuel de Conchyliologie et de Paléontologie Conchyliologique. Libraire F. Savy, Paris, 25, 1369 (non vide).

Foresti, L. 1876. Cenni geologici e paleontologici sul Pliocene antique di Castrocaro. Memoire Academia della Societa

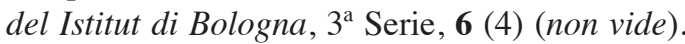

Glibert, M. \& van de Poel, L. 1965. Les Bivalvia fossiles du Cénozoïque étranger des collections de l'Institut Royal des Sciences Naturelles de Belgique. II. Pteroconchida, Colloconchida et Isofilibranchida. Mémoires du Musée Royal d'Histoire Naturelle de Belgique $2^{\text {nd }}$ Série, 78, 1-105.

Kidwell, S. M., Fürsich, F. T. \& Aigner, T. 1986. Conceptual framework for the analysis and classification of fossil concentrations. Palaios, 1, 228-238.

Lamarck, M. C. 1819. Histoire naturelle des animaux sans vertèbres. A. Berlin, Paris, 6, 343 pp. 
Linnaeus, C. 1758. Systema Naturae per Regna tria naturae. $10^{a}$ edition, reformata 1 (Regnum animale). Salvii, Stockoholm, $824 \mathrm{pp}$.

Martín, J. M., Braga, J. C. \& Betzler, C. 2003. Late NeogeneRecent uplift of the Cabo de Gata volcanic province, Almería, SE Spain. Geomorphology, 50, 27-42.

Martín, J. M., Braga, J. C., Aguirre, J. \& Betzler, C. 2004. Contrasting models of temperate carbonate sedimentation in a small Mediterranean embayment: the Pliocene Carboneras basin, SE Spain. Journal of the Geological Society of London, 161, 387-399.

Matsumoto, M. \& Hayami, I. 2000. Phylogenetic analysis of the family Pectinidae (Bivalvia) based on mitochondrial cytochrome $C$ oxidase subunit I. Journal of Molluscan Studies, 66, 477-488.

Méndez-Cecilia, M. A. 1971. Pectínidos pliocenos de Almería. Estudios Geológicos, 27, 487-495.

Montenat, C., Ott d'Estevou, P. \& La Chapelle, G. 1990. La bassin de Níjar-Carboneras et le couloir du bas-Andarax. In: Les bassins Néogènes du domaine Bétique oriental (Espagne): Tectonique et sédimentation dans un couloir de décrochement. Première partie. Étude régionale (Ed. C. Montenat). Documents et Travaux Institut Geologique Albert-de-Lapparent, 12-13, 129-164.

Monterosato, T. A. di. 1884. Nomenclatura generica e specifica di alcune conchiglie Mediterranee. Palermo, $152 \mathrm{pp}$.

Monterosato, T. A. di. 1889. Coquilles marines Marocaines. Journal de Conchyliologie, 37, 20-40.

Mörch, O. 1852-1853. Catalogus conchyliorum quae reliquit D. Alphonso, D. Aguirra et Gadea Comes de Yoldi, Pts. I and II. Havniae, 74 pp. (non vide).

Müller, O. F. 1776. Zoologiae Danicae prodomus, seu animalium Daniae et Norvegiae indigenarum characters, nomina, et synonyma imprimis popularium. Copenhagen, $281 \mathrm{pp}$. (non vide).

Newell, N. D. 1965. Classification of the Bivalvia. American Museum, 24 pp.

Newell, N. D. \& Boyd, D. W. 1995. Pectinoid bivalves of the Permian-Triassic crisis. Bulletin of the American Museum of the Natural History, 227, 1-95.

Nyst, P. H. \& Westendorp, 1839. Nouvelles recherches sur les coquilles de la province d'Anvers. Bulletin de l'Acadèmie des Sciences de Bruxelles, 4, 1-14.

Philippi, R. A. 1836. Enumeratio molluscorum Siciliae cum viventium tum in tellure Tertiaria fossilium quae in itinere suo observati (non vide).

Philippi, R. A. 1844. Enumeratio molluscorum Siciliae cum viventium tum in tellure Tertiaria fossilium quae in itinere suo observati, 2 . Halle (non vide).

Poli, J. X. 1795. Testaceae utriusque Siciliae eorumque historia et anatome, 2. Parma, 264 (non vide).

Rafinesque, C. S. 1815. Analyse de la Nature. Palermo: CS Rafinesque, from the Press of Jean Barravecchia (non vide).

Röding, P. F. 1798. Museum Boltenianum sive catalogues cimeliorum e tribus regnis naturae quae olim collegerat Joa. Fried. Bolten, M. D. p. d., Pars Secunda. Typis Johan Christi Trapii, Hamburg, 119 (non vide).
Roger, J. 1939. Le genre Chlamys dans les formations Néogènes de l'Europe. Mémoires de la Société Géologique de France, N.S. 17 (2-4), Mémoire 40, 1-294.

Rovereto, G. 1899. Rectification de nomenclatura. Revue critique de Paléozoologie, 3, 90 (non vide).

Saavedra, C. \& Peña, J. B. 2005. Nucleotide diversity and Pleistocene population expansion in Atlantic and Mediterranean scallops (Pecten maximus and P. jacobaeus) as revealed by the mitochondrial $16 \mathrm{~S}$ ribosomal RNA gene. Journal of Experimental Marine Biology and Ecology, 323, 138-150.

Saavedra, C. \& Peña, J. B. 2006. Phylogenetics of American scallops (Bivalvia: Pectinidae) based on partial 16S and $12 \mathrm{~S}$ ribosomal RNA gene sequences. Marine Biology, 150, 111-119.

Sacco, F. 1897. I molluschi dei terreni terziarii del Piemonte e Della Liguria. Parte 24 (Pectinidae). Carlo Clausen, Torino, $116 \mathrm{pp}$.

Simonelli, V. 1889. Terreni e fossili dell'Isola di Pianosa nel Mar Tirreno. Bolletino della Societá Geologica de Italia, 8 (non vide).

Stefani, G. \& Pantanelli, D. 1880. Molluschi pliocenici dei dintorni di Siena. Bulletin Della Societa malacologica Italiana, 4 (non vide).

von Teppner, W. 1922. Pars 15. Lamellibranchiata tertiaria. 'Anisomyaria' II. In: Fossilium Catalogus I: Animalia. Dr. W. Junk, Berlin (non vide).

Waller, T. R. 1991. Evolutionary relationships among commercial scallops (Mollusca: Bivalvia: Pectinidae). In: Scallops - biology, ecology and aquaculture II (Ed. S. E. Shumway). Elsevier, Amsterdam, 1-73.

Waller, T. R. 1993. The evolution of 'Chlamys' (Mollusca: Bivalvia: Pectinidae) in the tropical western Atlantic and eastern Pacific. American Malacological Bulletin, 10, 195-249.

Waller, T. R. 2006a. New phylogenies of the Pectinidae (Mollusca: Bivalvia): Reconciling morphological and molecular approaches. In: Scallops: biology, ecology and aquaculture II (Ed. S. E. Shumway). Elsevier, Amsterdam, $1-44$.

Waller, T. R. 2006b. Phylogeny of families in the Pectinoidea (Mollusca: Bivalvia): importance of the fossil record. Zoological Journal of the Linnean Society, 148, 313-342.

Waller T. R. \& Bongrain, M. 2006. Gigantopecten Rovereto, 1899 and Lissochlamys Sacco, 1897 (Mollusca, Bivalvia, PECTINIDAE): proposed conservation. Bulletin of Zoological Nomenclature, 63, 155-162.

Wilding, C. S., Beaumont, A. R. \& Latchford, J. W. 1999. Are Pecten maximus and Pecten jacobaeus different species? Journal of Marine Biological Association, 79, 949-952.

Wilkes, J. 1810. Conchology. Enciclopaedia Landinensis or Universal Dictionary of arts, sciences, and literature. Wilkes, London, 14-41.

Manuscrito recibido: 7 de Septiembre, 2007 Manuscrito aceptado: 29 de Enero, 2009 
Apéndice de medidas.

\section{Pecten planariae}

Valva Derecha

\begin{tabular}{|c|c|c|c|c|c|c|c|c|c|}
\hline $\mathrm{H}$ & L & $\begin{array}{l}\text { margen } \\
\text { ant. }\end{array}$ & $\begin{array}{l}\text { Aur. } \\
\text { Ant. }\end{array}$ & & $\begin{array}{l}\text { Aur. } \\
\text { ost. }\end{array}$ & & cost. & $\begin{array}{l}\text { L. } \\
\text { interc. }\end{array}$ & $\begin{array}{l}\mathrm{n}^{0} \\
\text { costillas }\end{array}$ \\
\hline & & & $\mathrm{H}$ & L & $\mathrm{H}$ & $\mathrm{L}$ & & & \\
\hline 98 & 117 & 68 & 21 & 29 & & & $\overline{6,6}$ & 4 & 12 \\
\hline 111 & 122 & 67 & & & 19 & 26 & 9,1 & 4,2 & 12 \\
\hline 92 & 103 & 48 & & & & & 7 & 4,1 & 13 \\
\hline 100,3 & 114,0 & 61,0 & 21,0 & 29,0 & 19,0 & 26,0 & 7,6 & 4,1 & 12,3 \\
\hline
\end{tabular}

Valva Izquierda

\begin{tabular}{|c|c|c|c|c|c|c|c|c|c|}
\hline & & $\begin{array}{l}\text { margen } \\
\text { ant. }\end{array}$ & $\begin{array}{l}\text { Aur. } \\
\text { Ant. }\end{array}$ & & $\begin{array}{l}\text { ur. } \\
\text { ost. }\end{array}$ & & L cost. & $\begin{array}{l}\text { L. } \\
\text { interc. }\end{array}$ & $\begin{array}{l}\mathrm{n}^{0} \\
\text { costillas }\end{array}$ \\
\hline & & & $\mathrm{H}$ & $\mathrm{L}$ & $\mathrm{H}$ & $\mathrm{L}$ & & & \\
\hline 90 & 117 & & 15 & 29 & & & 59 & 5, & \\
\hline 98 & 110 & 50 & 16 & 25 & 19 & & 59 & 6, & 11 \\
\hline 76 & 103 & 41 & 13 & 20 & 11 & 15 & 3,2 & 5, & 11 \\
\hline 88 & 110 & 45,5 & 14,7 & 24,7 & 15 & 15 & 5 & 6 , & 11 \\
\hline
\end{tabular}

\section{Pecten westendorpianus}

Valva Derecha

\begin{tabular}{|c|c|c|c|c|c|c|c|c|c|}
\hline & & $\begin{array}{l}\text { margen } \\
\text { ant. }\end{array}$ & $\begin{array}{l}\text { Aur. } \\
\text { Ant. }\end{array}$ & & $\begin{array}{l}\text { ur. } \\
\text { ost. }\end{array}$ & & cost. & $\begin{array}{l}\text { L. } \\
\text { interc. }\end{array}$ & $\begin{array}{l}\mathrm{n}^{0} \\
\text { costillas }\end{array}$ \\
\hline & & & $\mathrm{H}$ & $\mathrm{L}$ & $\mathrm{H}$ & $\mathrm{L}$ & & & \\
\hline 55 & 57 & 25 & 10 & 10 & & & 7 & 2,5 & 7 \\
\hline 46 & 51 & 20 & 8 & 11 & & & 6,7 & 1,9 & 7 \\
\hline 43 & 50 & 15 & & & 10 & 12 & 5,8 & 1,4 & 8 \\
\hline 48 & 52,7 & 20 & 9 & 10,5 & 10 & 12 & 6,5 & 1,9 & 7,3 \\
\hline
\end{tabular}

Valva Izquierda

\begin{tabular}{|c|c|c|c|c|c|c|c|c|}
\hline $\mathrm{L}$ & $\begin{array}{l}\text { margen } \\
\text { ant. }\end{array}$ & $\begin{array}{l}\text { Aur. } \\
\text { Ant. }\end{array}$ & & $\begin{array}{l}\text { Aur. } \\
\text { Post. }\end{array}$ & & L cost. & $\begin{array}{l}\text { L. } \\
\text { interc. }\end{array}$ & $\begin{array}{l}\mathrm{n}^{0} \\
\text { costillas }\end{array}$ \\
\hline & & $\mathrm{H}$ & $\mathrm{L}$ & $\mathrm{H}$ & $\mathrm{L}$ & & & \\
\hline & 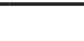 & 8 & 1 & & & & & 8 \\
\hline
\end{tabular}

\section{Pecten bipartitus}

Valva Derecha

\begin{tabular}{|c|c|c|c|c|c|c|c|c|c|}
\hline & & $\begin{array}{l}\text { margen } \\
\text { ant. }\end{array}$ & $\begin{array}{l}\text { Aur. } \\
\text { Ant. }\end{array}$ & & $\begin{array}{l}\text { ur. } \\
\text { st. }\end{array}$ & & cost. & $\begin{array}{l}\mathrm{L} . \\
\text { interc. }\end{array}$ & $\begin{array}{l}\mathrm{n}^{0} \\
\text { costillas }\end{array}$ \\
\hline & & & $\mathrm{H}$ & $\mathrm{L}$ & $\mathrm{H}$ & $\mathrm{L}$ & & & \\
\hline 59 & 65 & 32 & & & 14 & 15 & 3,8 & 2,4 & 11 \\
\hline 47 & 52 & 29 & 11 & 15 & & & 3,2 & 2 & 12 \\
\hline 43 & 45 & 27 & 9 & 12 & 10 & 14 & 3 & 2 & 11 \\
\hline 55 & 63 & 31 & & & 10 & 15 & 4,4 & 2 & 11 \\
\hline 41 & 45 & 25 & 10 & 12 & 12 & 13 & 2 & 2 & 12 \\
\hline 60 & 66 & 36 & 12 & 15 & 12 & 15 & 5,1 & 2,3 & 13 \\
\hline $\mathbf{5 0 , 8}$ & 56,0 & 30,0 & 10,5 & 13,5 & 11,6 & 14,4 & 3,6 & 2,1 & 11,7 \\
\hline
\end{tabular}

Valva Izquierda

\begin{tabular}{|c|c|c|c|c|c|c|c|c|c|}
\hline $\mathrm{H}$ & $\mathrm{L}$ & $\begin{array}{l}\text { margen } \\
\text { ant. }\end{array}$ & $\begin{array}{l}\text { Aur. } \\
\text { Ant. }\end{array}$ & & $\begin{array}{l}\text { ur. } \\
\text { ost. }\end{array}$ & & cost. & $\begin{array}{l}\text { L. } \\
\text { interc. }\end{array}$ & $\begin{array}{l}\mathrm{n}^{0} \\
\text { costillas }\end{array}$ \\
\hline & & & $\mathrm{H}$ & $\mathrm{L}$ & $\mathrm{H}$ & $\mathrm{L}$ & & & \\
\hline 47 & 57 & 25 & 8 & 16 & 9 & 16 & 2,3 & 3,3 & 11 \\
\hline 45 & 52 & 20 & 6 & 11 & 10 & 12 & 2 & 2,6 & 11 \\
\hline 41 & 45 & 24 & 9 & 14 & 10 & 13 & 1,9 & 1,9 & 11 \\
\hline 50 & 58 & 27 & 10 & & 10 & 17 & 2,1 & 3,8 & 11 \\
\hline 40 & 45 & 22 & 9 & 14 & 9 & 14 & 2 & 2 & 11 \\
\hline 55 & 63 & 30 & 10 & 17 & 11 & 17 & 2,6 & 4 & 11 \\
\hline 46,3 & 53,3 & 24,7 & 8,7 & 14,4 & 9,8 & 14,8 & 2,2 & 2,9 & 11,0 \\
\hline
\end{tabular}

\section{Pecten maximus}

Valva Derecha

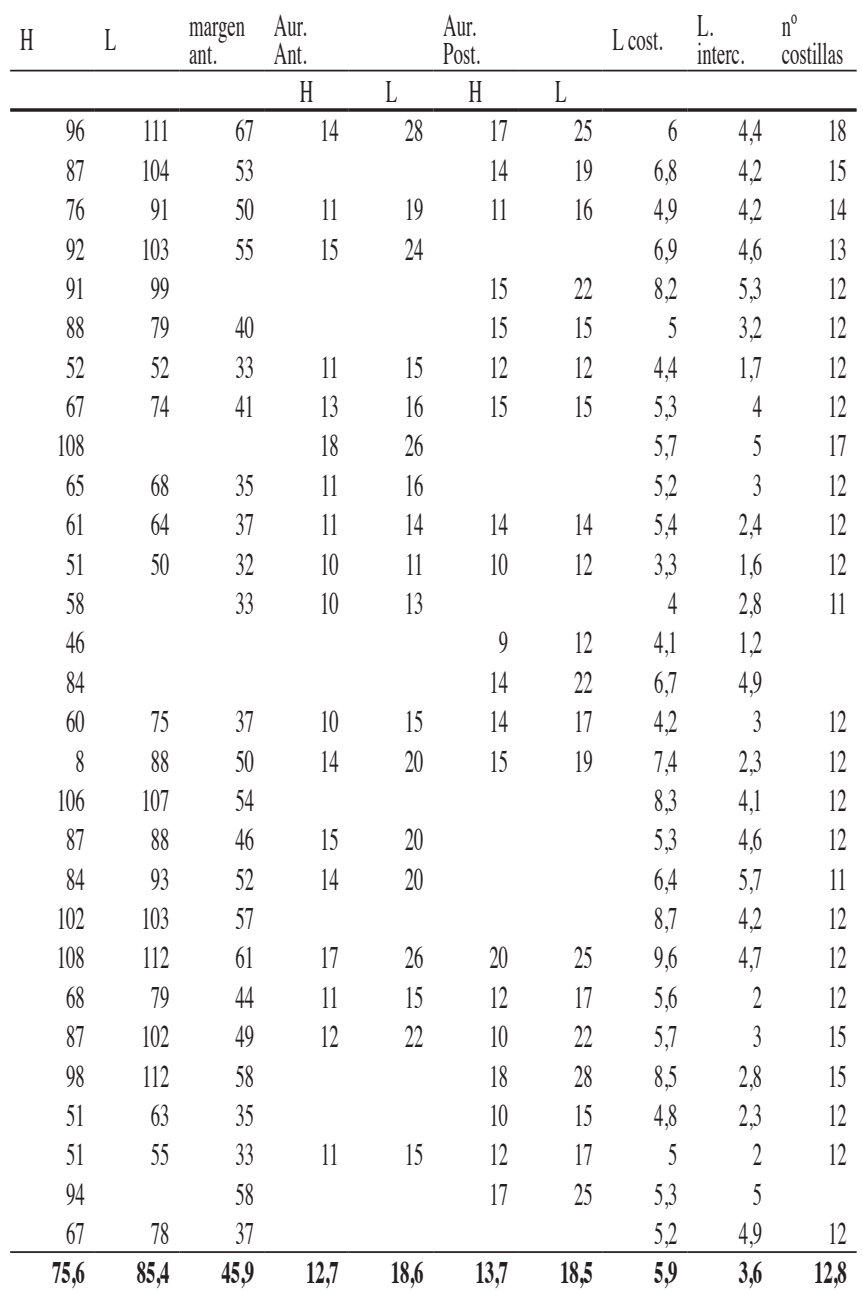

Valva Izquierda

\begin{tabular}{|c|c|c|c|c|c|c|c|c|c|}
\hline & & $\begin{array}{l}\text { margen } \\
\text { ant. }\end{array}$ & $\begin{array}{l}\text { Aur. } \\
\text { Ant. }\end{array}$ & & ur. & & cost. & $\begin{array}{l}\mathrm{L} . \\
\text { interc. }\end{array}$ & $\begin{array}{l}\mathrm{n}^{0} \\
\text { costillas }\end{array}$ \\
\hline & & & $\mathrm{H}$ & $\mathrm{L}$ & $\mathrm{H}$ & $\mathrm{L}$ & & & \\
\hline 85 & 107 & 50 & 17 & 26 & 20 & 27 & 5,5 & 5,1 & 16 \\
\hline 75 & 93 & 45 & 12 & 22 & 13 & 21 & 4,1 & 6,8 & 13 \\
\hline 62 & 75 & 45 & 11 & 20 & 11 & 20 & 4,2 & 5,6 & 12 \\
\hline 78 & 100 & 35 & & & 14 & 25 & 5 & 6,4 & 12 \\
\hline 71 & 92 & & & & 15 & 22 & 3,1 & 6,3 & 13 \\
\hline 60 & 68 & 32 & & & 11 & 15 & 3,1 & 5,2 & 11 \\
\hline 46 & 50 & 22 & 10 & 14 & & & 2,4 & 4,3 & 10 \\
\hline 63 & 72 & 32 & 10 & 18 & & & 4 & 5,2 & 11 \\
\hline 92 & & & 15 & 28 & 16 & 25 & 4,8 & 6,3 & 15 \\
\hline 56 & 68 & & 11 & 16 & 10 & 15 & 4 & 4,5 & 12 \\
\hline 55 & 63 & 25 & 10 & 14 & 12 & 14 & 3,1 & 5,2 & 11 \\
\hline 40 & 45 & 21 & 7 & 10 & 8 & 12 & 2,5 & 3,3 & 11 \\
\hline 48 & & 25 & 10 & 13 & & & 3,2 & 3,8 & \\
\hline 40 & 44 & 24 & & & 9 & 13 & 2 & 3,4 & 11 \\
\hline 75 & & & 10 & 18 & 15 & 20 & 5 & 5,8 & 11 \\
\hline 50 & & 30 & 10 & 16 & 11 & 16 & 3 & 5,1 & 11 \\
\hline 5 & 57 & 29 & 9 & 15 & & & 2,1 & 4 & 11 \\
\hline 38 & 41 & 21 & 8 & 12 & 9 & 14 & 1,9 & 3,3 & 10 \\
\hline 49 & & & & & 10 & 14 & 2,4 & 4,6 & \\
\hline 44 & & 25 & 9 & 14 & 11 & 15 & 2 & 2,6 & 13 \\
\hline 68 & 83 & 35 & 11 & 19 & 11 & 20 & 4,6 & 5,8 & 11 \\
\hline $\mathbf{5 7 , 1}$ & 70,5 & 31,0 & 10,6 & 17,2 & 12,1 & 18,1 & 3,4 & 4,9 & 11,8 \\
\hline
\end{tabular}


Gigantopecten latissima

Valva Derecha

\begin{tabular}{|c|c|c|c|c|c|c|c|c|c|}
\hline & $\mathrm{L}$ & $\begin{array}{l}\text { margen } \\
\text { ant. }\end{array}$ & $\begin{array}{l}\text { Aur. } \\
\text { Ant. }\end{array}$ & & $\begin{array}{l}\text { ur. } \\
\text { ost. }\end{array}$ & & $L$ cost. & $\begin{array}{l}\text { L. } \\
\text { interc. }\end{array}$ & $\begin{array}{l}\mathrm{n}^{0} \\
\text { costillas }\end{array}$ \\
\hline & & & $\mathrm{H}$ & $\mathrm{L}$ & $\mathrm{H}$ & $\mathrm{L}$ & & & \\
\hline 112 & 125 & 54 & & & & & 13,3 & 14,2 & 6 \\
\hline 86 & & & & & 20 & 32 & 11,3 & 12,3 & 6 \\
\hline 205 & 210 & 111 & & & 32 & 65 & 29,7 & 25,7 & 6 \\
\hline 134,3 & 167,5 & 82,5 & & & 26,0 & 48,5 & 18,1 & 17,4 & 6,0 \\
\hline
\end{tabular}

Valva Izquierda

\begin{tabular}{|c|c|c|c|c|c|c|c|c|c|}
\hline & & $\begin{array}{l}\text { margen } \\
\text { ant. }\end{array}$ & $\begin{array}{l}\text { Aur. } \\
\text { Ant. }\end{array}$ & & $\begin{array}{l}\text { ur. } \\
\text { ost. }\end{array}$ & & cost. & $\begin{array}{l}\mathrm{L} . \\
\text { interc. }\end{array}$ & $\begin{array}{l}\mathrm{n}^{0} \\
\text { costillas }\end{array}$ \\
\hline & & & $\mathrm{H}$ & $\mathrm{L}$ & $\mathrm{H}$ & $\mathrm{L}$ & & & \\
\hline 112 & 123 & 72 & 21 & 40 & 25 & 43 & 14,6 & 12,5 & 5 \\
\hline 205 & 210 & & & & & & & & \\
\hline 158,5 & 166,5 & 72 & 21 & 40 & 25 & 43 & 14,6 & 12,5 & 5 \\
\hline
\end{tabular}

\section{Flabellipecten alesii}

Valva Derecha

\begin{tabular}{|c|c|c|c|c|c|c|c|c|c|}
\hline & L & $\begin{array}{l}\text { margen } \\
\text { ant. }\end{array}$ & $\begin{array}{l}\text { Aur. } \\
\text { Ant. }\end{array}$ & & $\begin{array}{l}\text { ur. } \\
\text { ost. }\end{array}$ & & L cost. & $\begin{array}{l}\text { L. } \\
\text { interc. }\end{array}$ & $\begin{array}{l}\mathrm{n}^{0} \\
\text { costillas }\end{array}$ \\
\hline & & & $\mathrm{H}$ & $\mathrm{L}$ & $\mathrm{H}$ & $\mathrm{L}$ & & & \\
\hline 107 & 120 & 50 & 14 & 21 & 12 & 24 & & & \\
\hline 106 & 116 & 54 & 14 & 23 & 14 & 25 & & & \\
\hline 100 & 115 & 51 & 14 & 19 & 12 & 18 & & & \\
\hline 80 & 96 & & & & & & & & \\
\hline 98,3 & 111,8 & 51,7 & 14,0 & 21,0 & 12,7 & 22,3 & & & \\
\hline
\end{tabular}

\begin{tabular}{|c|c|c|c|c|c|c|c|c|}
\hline \multicolumn{9}{|c|}{ Valva Izquierda } \\
\hline $\mathrm{H}$ & $\mathrm{L}$ & $\begin{array}{l}\text { margen } \\
\text { ant. }\end{array}$ & $\begin{array}{l}\text { Aur. } \\
\text { Ant. }\end{array}$ & & $\begin{array}{l}\text { ur. } \\
\text { ost. }\end{array}$ & L cost. & $\begin{array}{l}\text { L. } \\
\text { interc. }\end{array}$ & $\begin{array}{l}\mathrm{n}^{0} \\
\text { costillas }\end{array}$ \\
\hline & & & $\mathrm{H}$ & $\mathrm{L}$ & $\mathrm{H}$ & $\mathrm{L}$ & & \\
\hline 80 & 96 & 42 & 10 & 20 & 10 & 20 & & \\
\hline 105 & 111 & 47 & 14 & 23 & 12 & 22 & & \\
\hline 101 & 109 & 40 & 14 & 22 & 11 & 25 & & \\
\hline 102 & 110 & 40 & & & 9 & 19 & & \\
\hline 97 & 106,5 & 42,25 & 12,7 & 21,7 & 10,5 & 21,5 & & \\
\hline
\end{tabular}

\section{Amusium cristatum}

Valva Derecha

\begin{tabular}{|c|c|c|c|c|c|c|c|c|}
\hline $\mathrm{H}$ & L & $\begin{array}{l}\text { margen } \\
\text { ant. }\end{array}$ & $\begin{array}{l}\text { Aur. } \\
\text { Ant. }\end{array}$ & & $\begin{array}{l}\text { ur. } \\
\text { ost. }\end{array}$ & L cost. & $\begin{array}{l}\text { L. } \\
\text { interc. }\end{array}$ & $\begin{array}{l}\mathrm{n}^{0} \\
\text { costillas }\end{array}$ \\
\hline & & & $\mathrm{H}$ & $\mathrm{L}$ & $\mathrm{H}$ & $\mathrm{L}$ & & \\
\hline 96 & 100 & & 9 & 17 & 9 & 20 & & 25 \\
\hline 94 & 99 & 35 & 11 & 17 & 10 & 15 & & \\
\hline 82 & 90 & 30 & 9 & 15 & 9 & 14 & & \\
\hline 92 & 96 & 35 & 12 & 14 & 12 & 14 & & \\
\hline 85 & 85 & 34 & 10 & 14 & 11 & 14 & & \\
\hline 92 & 97 & 35 & 10 & 16 & 9 & 15 & & \\
\hline 81 & 85 & 33 & 10 & 16 & 10 & 15 & & \\
\hline 62 & 60 & 25 & 7 & 10 & 6 & 10 & & \\
\hline 94 & 99 & 35 & 10 & 17 & 11 & 15 & & \\
\hline 80 & 91 & 36 & 12 & 15 & 11 & 15 & & \\
\hline 86 & 90 & 34 & 10 & 17 & & & & \\
\hline 102 & 103 & 33 & 11 & 16 & 12 & 14 & & \\
\hline 40 & 44 & 19 & 6 & 8 & 7 & 8 & & 27 \\
\hline 92 & 92 & 33 & 10 & 13 & 11 & 13 & & \\
\hline 62 & 65 & 28 & 9 & 11 & & & & 28 \\
\hline 35 & 32 & & 5 & 5 & 5 & 5 & & 28 \\
\hline 30 & 30 & 19 & 5 & 6 & 5 & 6 & & 25 \\
\hline 25 & 25 & 12 & 3 & 5 & 3 & 5 & & 24 \\
\hline 35 & 34 & 15 & 5 & 6 & 5 & 4 & & \\
\hline 23 & 23 & 10 & 3 & 5 & 4 & 4 & & \\
\hline 20 & 20 & 9 & 3 & 3 & 3 & 3 & & \\
\hline 17 & 18 & 8 & 3 & 3 & 3 & 3 & & \\
\hline 15 & 14 & 8 & 3 & 3 & 3 & 3 & & \\
\hline 62,6 & 64,9 & 25,0 & 7,7 & 11,0 & 7,6 & 10,2 & & 26,2 \\
\hline
\end{tabular}

Valva Izquierda

\begin{tabular}{|c|c|c|c|c|c|c|c|c|}
\hline \multirow[t]{2}{*}{$\begin{array}{lll}\mathrm{H} & \mathrm{L} \\
\end{array}$} & & \multirow[t]{2}{*}{$\begin{array}{l}\text { margen } \\
\text { ant. }\end{array}$} & \multirow{2}{*}{$\begin{array}{c}\text { Aur. } \\
\text { Ant. } \\
\mathrm{H} \\
\end{array}$} & \multicolumn{2}{|c|}{$\begin{array}{l}\text { Aur. } \\
\text { Post. }\end{array}$} & L cost. & \multirow[t]{2}{*}{$\begin{array}{l}\text { L. } \\
\text { interc. }\end{array}$} & \multirow[t]{2}{*}{$\begin{array}{l}\mathrm{n}^{0} \\
\text { costillas }\end{array}$} \\
\hline & & & & $\mathrm{L}$ & $\mathrm{H}$ & $\mathrm{L}$ & & \\
\hline 94 & 100 & & 10 & 19 & 9 & 19 & & 27 \\
\hline 94 & 98 & 32 & 10 & 18 & 9 & 16 & & 23 \\
\hline 83 & 90 & 25 & 9 & 15 & 8 & 13 & & 23 \\
\hline 80 & 82 & 26 & 11 & 15 & 9 & 14 & & \\
\hline 96 & 100 & 28 & 10 & 17 & 11 & 19 & & \\
\hline 90 & & 30 & 10 & 15 & 9 & 15 & & \\
\hline 85 & 90 & 30 & 10 & 16 & 9 & 15 & & \\
\hline 90 & 90 & 29 & 10 & 17 & 8 & 16 & & \\
\hline 45 & 47 & 19 & 6 & 9 & 6 & 9 & & \\
\hline 47 & 44 & 19 & 6 & 7 & & & & \\
\hline 42 & 43 & 17 & 5 & 8 & 5 & 7 & & \\
\hline 43 & 46 & 16 & 5 & 5 & 4 & 5 & & 24 \\
\hline 31 & 31 & 13 & 5 & 5 & 5 & 5 & & 24 \\
\hline 31 & & 13 & 4 & 5 & 4 & 5 & & 27 \\
\hline 29 & 28 & 13 & 4 & 6 & 3 & 5 & & 22 \\
\hline 25 & 24 & 11 & 4 & 5 & 4 & 4 & & 22 \\
\hline 25 & 24 & 10 & 3 & 4 & 3 & 4 & & 22 \\
\hline 24 & 22 & & 4 & 4 & 3 & 4 & & 24 \\
\hline 22 & 21 & 10 & 3 & 4 & 3 & 3 & & \\
\hline 21 & 18 & 9 & 3 & 4 & 2 & 3 & & \\
\hline 54,9 & 55,4 & 19,4 & 6,6 & 9,9 & 6,0 & 9,5 & & 23,8 \\
\hline
\end{tabular}




\section{Flabellipecten bosniasckii}

Valva Derecha

\begin{tabular}{|c|c|c|c|c|c|c|c|c|c|}
\hline & L & $\begin{array}{l}\text { margen } \\
\text { ant. }\end{array}$ & $\begin{array}{l}\text { Aur. } \\
\text { Ant. }\end{array}$ & & ur. & & cost. & $\begin{array}{l}\text { L. } \\
\text { interc. }\end{array}$ & $\begin{array}{l}\mathrm{n}^{0} \\
\text { costillas }\end{array}$ \\
\hline & & & $\mathrm{H}$ & $\mathrm{L}$ & $\mathrm{H}$ & $\mathrm{L}$ & & & \\
\hline 92,8 & 103 & 59 & & & & & 4,1 & 2,2 & 27 \\
\hline 94 & 103,5 & 55 & 15 & 24 & 15 & 25 & 4,7 & 1,5 & 22 \\
\hline 85,7 & 95 & 52 & 17 & 21 & 16 & 22,3 & 3,9 & 1,4 & 20 \\
\hline 78 & 82 & 44 & 16 & 19,5 & 13,6 & 19 & 3,5 & 1,6 & 21 \\
\hline 84,1 & 89,3 & & & & 15 & 21 & 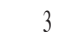 & 1,7 & 25 \\
\hline 68 & 74,5 & 41 & & & 11 & 21 & 2,7 & 1,9 & 20 \\
\hline 70,7 & 73,6 & 45 & & & 11 & 17 & 3 & 2,5 & 23 \\
\hline 81,9 & 88,7 & 49,3 & 16 & 21,5 & 13,6 & 20,9 & 3,6 & 1,8 & 22,6 \\
\hline
\end{tabular}

Valva Izquierda

\begin{tabular}{|c|c|c|c|c|c|c|c|c|c|}
\hline & & $\begin{array}{l}\text { margen } \\
\text { ant. }\end{array}$ & $\begin{array}{l}\text { Aur. } \\
\text { Ant. }\end{array}$ & & & & cost. & $\begin{array}{l}\text { L. } \\
\text { interc. }\end{array}$ & $\begin{array}{l}\mathrm{n}^{0} \\
\text { costillas }\end{array}$ \\
\hline & & & $\mathrm{H}$ & $\mathrm{L}$ & $\mathrm{H}$ & $\mathrm{L}$ & & & \\
\hline 85,3 & 90,8 & 53 & 13 & 24,3 & 14 & 25 & 2,4 & 3,7 & 16 \\
\hline 91,4 & 95,6 & 56,5 & 14 & 24,5 & 15 & 23 & 2,2 & 3,4 & 18 \\
\hline 90,4 & 101,7 & 54 & & & 17 & 21 & 1,8 & 3,7 & 22 \\
\hline 75 & 79,8 & 53 & 14 & 15,5 & 14 & 20 & 2 & 3,3 & 17 \\
\hline & 84,6 & & & & 13 & 26 & 2 & 3 & 15 \\
\hline 65,4 & 69,6 & 34,3 & & 23 & 12 & 19 & & & 19 \\
\hline 81,5 & 87,0 & 50,2 & 13,7 & 21,8 & 14,2 & 23,3 & 2,1 & 3,4 & 17,8 \\
\hline
\end{tabular}

\section{Flabellipecten flabelliformis}

Valva Derecha

\begin{tabular}{|c|c|c|c|c|c|c|c|c|c|}
\hline & & $\begin{array}{l}\text { margen } \\
\text { ant. }\end{array}$ & $\begin{array}{l}\text { Aur. } \\
\text { Ant. }\end{array}$ & & $\begin{array}{l}\text { ur. } \\
\text { ost. }\end{array}$ & & cost. & $\begin{array}{l}\text { L. } \\
\text { interc. }\end{array}$ & $\begin{array}{l}\mathrm{n}^{0} \\
\text { costillas }\end{array}$ \\
\hline & & & $\mathrm{H}$ & $\mathrm{L}$ & $\mathrm{H}$ & $\mathrm{L}$ & & & \\
\hline 81,8 & 83,2 & 49,5 & 14,5 & 20 & 12 & 23 & 3,5 & 1 & 26 \\
\hline 86,4 & 94 & 55 & 15 & 22 & 15 & 25 & 3,9 & 2 & 23 \\
\hline 101,4 & & & & & & & 3,1 & 2 & 28 \\
\hline 74 & 82 & 45 & & & & & 3,6 & 1 & 23 \\
\hline 68,6 & 72,8 & 45 & & & 13 & 18 & 2,7 & 1,1 & 25 \\
\hline 45,4 & 47,8 & 28 & 9 & 10 & 10 & 10 & 2,1 & 1 & 21 \\
\hline 46,3 & 50 & & 10 & 13 & 10,5 & & 2 & 1 & 23 \\
\hline 72,0 & 71,6 & 44,5 & 12,1 & 16,3 & 12,1 & 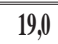 & $3,3,0$ & $1,1,3$ & 24,1 \\
\hline
\end{tabular}

Valva Izquierda

\begin{tabular}{|c|c|c|c|c|c|c|c|c|c|}
\hline \multirow[t]{2}{*}{$\mathrm{H}$} & \multirow[t]{2}{*}{ L } & \multirow{2}{*}{$\begin{array}{l}\text { margen } \\
\text { ant. }\end{array}$} & \multirow{2}{*}{$\begin{array}{c}\text { Aur. } \\
\text { Ant. } \\
\mathrm{H}\end{array}$} & \multicolumn{2}{|c|}{$\begin{array}{l}\text { Aur. } \\
\text { Post. }\end{array}$} & \multicolumn{2}{|c|}{ L cost. } & \multirow[t]{2}{*}{$\begin{array}{l}\text { L. } \\
\text { interc. }\end{array}$} & \multirow[t]{2}{*}{$\begin{array}{l}\mathrm{n}^{0} \\
\text { costillas }\end{array}$} \\
\hline & & & & $\mathrm{L}$ & $\mathrm{H}$ & L & & & \\
\hline 86,3 & 89,3 & 47 & 14 & 25 & 13 & 28 & 2 & 3,9 & 21 \\
\hline 79,8 & 82,1 & 42 & 12 & 24 & 11 & 23 & 2,8 & 1,9 & 22 \\
\hline 101,4 & & 55 & 16 & 28 & 15 & 29 & 1,9 & 3,3 & 21 \\
\hline 73 & 79 & 33 & 10 & 21 & 10 & 25 & 1,9 & 3,2 & 18 \\
\hline 45 & 48 & 20 & 10 & 14 & 10 & 14 & 1 & 1,8 & 19 \\
\hline 45 & 47 & 22 & 10 & 11 & 9 & 12 & 1 & 2 & 17 \\
\hline 73 & 80 & 30 & 12 & 19 & 10 & 20 & 3 & 3 & 16 \\
\hline & 115 & 50 & 16 & 30 & 16 & 32 & 3 & 3,6 & 22 \\
\hline 59 & 73,8 & 31 & 11,6 & 19 & 11 & 20,6 & 1,98 & 2,72 & 18,4 \\
\hline
\end{tabular}

\section{Korobkovia oblonga}

Valva Derecha

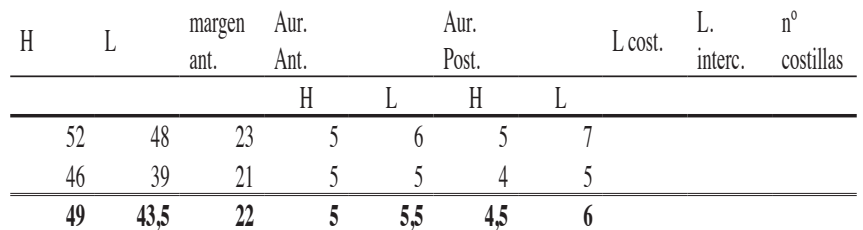

Valva Izquierda

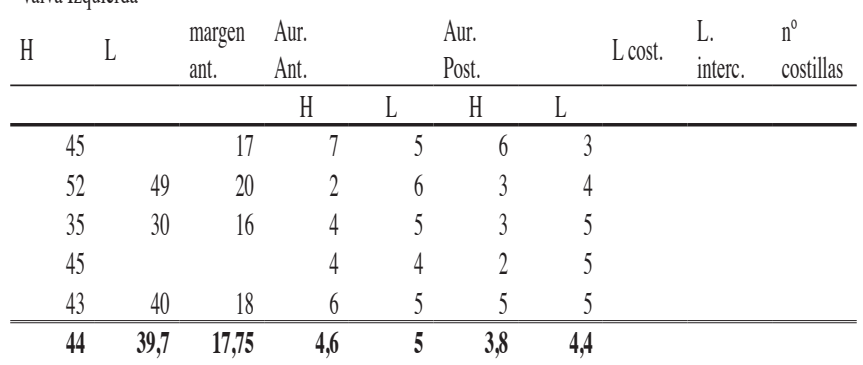

\section{Palliolum excisum}

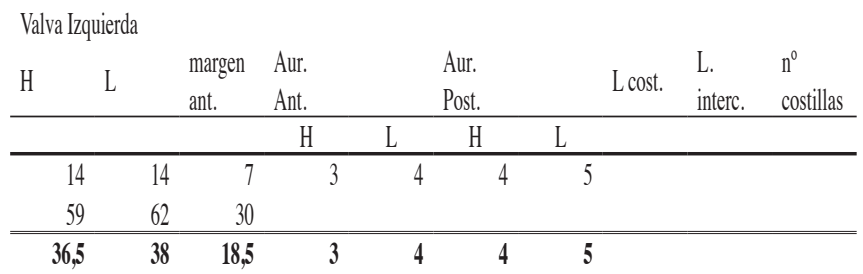

\section{Palliolum tigerinum}

\begin{tabular}{|c|c|c|c|c|c|c|c|c|}
\hline \multicolumn{9}{|c|}{ Valva Derecha } \\
\hline $\mathrm{H}$ & $\mathrm{L}$ & $\begin{array}{l}\text { margen } \\
\text { ant. }\end{array}$ & $\begin{array}{l}\text { Aur. } \\
\text { Ant. }\end{array}$ & & $\begin{array}{l}\text { Aur. } \\
\text { Post. }\end{array}$ & L cost. & $\begin{array}{l}\text { L. } \\
\text { interc. }\end{array}$ & $\begin{array}{l}\mathrm{n}^{0} \\
\text { costillas }\end{array}$ \\
\hline & & & $\mathrm{H}$ & $\mathrm{L}$ & $\mathrm{H}$ & $\mathrm{L}$ & & \\
\hline 2 & 19 & 10 & 4 & 8 & 3 & 4 & & \\
\hline 2 & 20 & 10 & 4 & 7 & 2 & 2 & & \\
\hline 2 & 19,5 & 10 & 4 & $\overline{7,5}$ & 2,5 & 3 & & \\
\hline
\end{tabular}


Pseudoamussium clavatum

\begin{tabular}{|c|c|c|c|c|c|c|c|c|c|}
\hline \multicolumn{10}{|l|}{ alva Dere } \\
\hline & L & $\begin{array}{l}\text { margen } \\
\text { ant. }\end{array}$ & $\begin{array}{l}\text { Aur. } \\
\text { Ant. }\end{array}$ & & & & cost. & $\begin{array}{l}\text { L. } \\
\text { interc. }\end{array}$ & $\begin{array}{l}\mathrm{n}^{0} \\
\text { costillas }\end{array}$ \\
\hline & & & $\mathrm{H}$ & $\mathrm{L}$ & $\mathrm{H}$ & L & & & \\
\hline 33 & 32 & 15 & 5 & 6 & 4 & 4 & 7,3 & 3,7 & 4 \\
\hline 22 & 21 & 10 & 4 & 5 & 3 & 3 & 3,7 & 4 & 3 \\
\hline 44 & 44 & 24 & 7 & 9 & 7 & 5 & 6 & 3,3 & 5 \\
\hline 25 & 24 & 12 & 4 & 5 & 4 & 3 & 3,6 & 3,3 & 4 \\
\hline 30 & 27 & 15 & 5 & 6 & 5 & 3 & 5,5 & 3,7 & 4 \\
\hline 27 & 26 & 12 & 4 & 4 & & & 5,5 & 3,7 & 4 \\
\hline 27 & 26 & 16 & 5 & 6 & 5 & 4 & 5,7 & 3,5 & 3 \\
\hline 33 & 32 & 15 & 5 & 4 & 4 & 4 & 6,8 & 4,3 & 4 \\
\hline 36 & 34 & 18 & 5 & 7 & 6 & 4 & 7,3 & 3,7 & 4 \\
\hline 27 & 25 & 15 & & & 3 & 4 & 4,5 & 3 & 4 \\
\hline 24 & 23 & 13 & 4 & 6 & 4 & 3 & 3,3 & 3,3 & 4 \\
\hline 22 & 21 & 12 & 3 & 5 & 3 & 3 & 3,8 & 2,3 & 4 \\
\hline 21 & 21 & 13 & 3 & 5 & 4 & 3 & 3,4 & 2,7 & 4 \\
\hline 23 & 21 & 13 & 4 & 4 & 4 & 3 & 3,3 & 2,2 & 4 \\
\hline 22 & 21 & 12 & 4 & 5 & 3 & 3 & 3,8 & 2,2 & 4 \\
\hline 21 & 20 & 12 & 4 & 5 & 4 & 3 & 3,1 & 2,5 & 4 \\
\hline 30 & 30 & 17 & 5 & 7 & 4 & 4 & 5,3 & 3,5 & 4 \\
\hline 25 & 24 & 13 & 4 & 5 & 3 & 3 & 4,3 & 3 & 3 \\
\hline 31 & 30 & 15 & 4 & 5 & 3 & 4 & 5 & 3,3 & 4 \\
\hline 19 & 19 & 10 & 3 & 4 & 3 & 3 & 3,4 & 1,7 & 4 \\
\hline 41 & 40 & 20 & 5 & 7 & 4 & 4 & 9,3 & 3,5 & 4 \\
\hline 34 & 34 & 23 & 6 & 8 & 6 & 5 & 8 & 3 & 3 \\
\hline 24 & 21 & 11 & 3 & 5 & 4 & 3 & 4,8 & 2,2 & 4 \\
\hline 26 & 26 & 14 & 4 & 6 & 4 & 4 & 4,3 & 2,8 & 4 \\
\hline 28 & 27 & 16 & 5 & 6 & 4 & 3 & 4,5 & 2,7 & 4 \\
\hline 31 & 30 & 17 & 5 & 5 & 3 & 4 & 5,3 & 3 & 4 \\
\hline 30 & 29 & 16 & 5 & 6 & 4 & 4 & 5,8 & 2,7 & 4 \\
\hline 28 & 27 & 14 & 4 & 6 & & & 5,3 & 2,5 & 4 \\
\hline 23 & 23 & 14 & 4 & 5 & & & 4 & 2,5 & 4 \\
\hline 17 & 17 & 10 & 3 & 5 & 3 & 3 & 2,6 & 2 & 4 \\
\hline 33 & 32 & 16 & 5 & 7 & 4 & 5 & 5,8 & 3 & 4 \\
\hline 27,6 & 26,7 & 14,6 & 4,4 & 5,6 & 4,0 & 3,6 & 5,0 & 3,0 & 3,9 \\
\hline
\end{tabular}

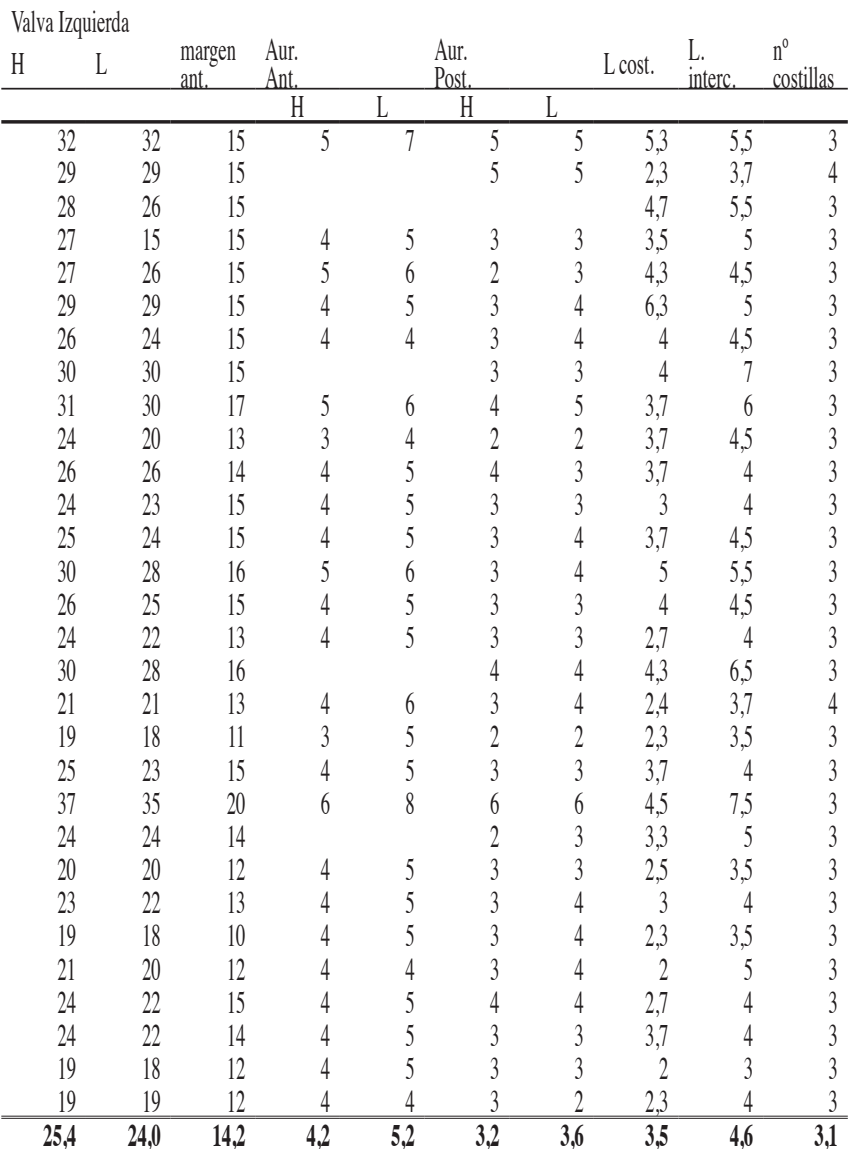

\section{Aequipecten angelonii}

Valva Derecha

\begin{tabular}{|c|c|c|c|c|c|c|c|c|c|}
\hline & & $\begin{array}{l}\text { margen } \\
\text { ant. }\end{array}$ & $\begin{array}{l}\text { Aur. } \\
\text { Ant. }\end{array}$ & & $\begin{array}{l}\text { ur. } \\
\text { ost. }\end{array}$ & & cost. & $\begin{array}{l}\text { L. } \\
\text { interc. }\end{array}$ & $\begin{array}{l}\mathrm{n}^{0} \\
\text { costillas }\end{array}$ \\
\hline & & & $\mathrm{H}$ & L & $\mathrm{H}$ & L & & & \\
\hline 48 & 48 & 27 & 10 & 17 & 7 & 12 & 1,8 & 1,2 & 20 \\
\hline 57 & 56 & 27 & 10 & 17 & 10 & 14 & 2,1 & 1,7 & 20 \\
\hline 43 & 40 & 22 & 8 & 14 & 8 & 8 & 1,3 & 2 & 19 \\
\hline 45 & 44 & 24 & 7 & 14 & 5 & 8 & 1,4 & 1,6 & 21 \\
\hline 59 & 59 & 28 & 10 & 18 & 10 & 14 & 1,8 & 1,8 & 21 \\
\hline 59 & 56 & 27 & 10 & 18 & 8 & 13 & 1,8 & 1,9 & 20 \\
\hline 52 & 52 & 27 & 8 & 15 & 8 & 11 & 1,7 & 1,5 & 20 \\
\hline 56 & 56 & 23 & 9 & 17 & 8 & 12 & 1,7 & 1,9 & 20 \\
\hline 60 & 68 & 35 & 10 & 19 & 10 & 10 & 1,8 & 1,8 & 22 \\
\hline 49 & 49 & 24 & 9 & 15 & 10 & 11 & 1,8 & 1,9 & 18 \\
\hline 54 & 54 & 28 & 10 & 17 & 9 & 12 & 1,9 & 1,5 & 20 \\
\hline 64 & 65 & 30 & 10 & 19 & 10 & 10 & 2,2 & 1,5 & 21 \\
\hline 51 & 52 & 25 & 9 & 17 & 9 & 13 & 1,4 & 1,7 & 22 \\
\hline 41 & 40 & 22 & 7 & 13 & 7 & 10 & 1,3 & 1,1 & 19 \\
\hline 50 & 50 & 29 & 12 & 15 & 5 & 6 & 1,6 & 1,6 & 18 \\
\hline 55 & 57 & 32 & 10 & 17 & 7 & 10 & 1,8 & 1,7 & 19 \\
\hline 32 & 30 & 16 & 5 & 12 & 4 & 6 & 1 & 0,9 & 20 \\
\hline 32 & 30 & 17 & 5 & 9 & 5 & 5 & 1,6 & 1 & 20 \\
\hline 32 & 29 & 16 & 5 & 11 & 5 & 5 & 1 & 0,8 & 23 \\
\hline 56 & 56 & 29 & 9 & 17 & 9 & 12 & 1,9 & 1,8 & 19 \\
\hline 49, & 49,0 & 25,4 & 8,7 & 15,6 & 7,7 & 10,1 & 1,6 & 1,5 & 20,1 \\
\hline
\end{tabular}

Valva Izquierda

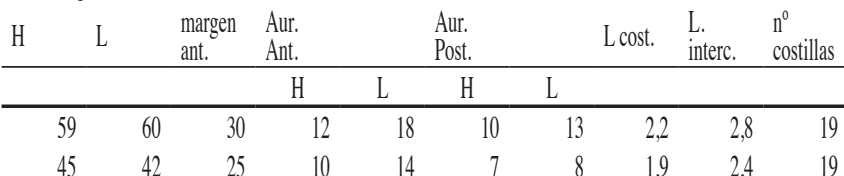
$\begin{array}{llllllll}47 & 47 & 23 & 9 & 11 & 1,9 & 2 & 20\end{array}$ $\begin{array}{llllll}65 & 10 & 11 & 3 & 4,3 & 16\end{array}$ $\begin{array}{llllllllll}44 & 42 & 25 & 10 & 15 & 4 & 8,5 & 2 & 2 & 20\end{array}$ $\begin{array}{llllllllll}39 & 37 & 21 & 9 & 13 & 5 & 6 & 1,6 & 1,8 & 20\end{array}$ $\begin{array}{llllllllll}71 & 69 & 35 & 10 & 15 & 6 & 7 & 2,4 & 2,3 & 23\end{array}$ $\begin{array}{llllllllll}65 & 66 & 35 & 13 & 20 & 12 & 14 & 2,6 & 2,4 & 20\end{array}$ $\begin{array}{llllllll}64 & 61 & 34 & 10 & 13 & 2,5 & 2,6 & 19\end{array}$ $\begin{array}{llllllllll}59 & 59 & 30 & 12 & 15 & 8 & 8 & 2,5 & 2,3 & 18\end{array}$ $\begin{array}{llllllllll}64 & 62 & 32 & 12 & 17 & 11 & 12 & 2,3 & 2 & 19\end{array}$ $\begin{array}{llllllll}60 & 62 & 32 & 11 & 10 & 2 & 2,9 & 20\end{array}$ $\begin{array}{llllllllll}65 & 66 & 33 & 12 & 18 & 8 & 12 & 2,3 & 2,7 & 20\end{array}$ $\begin{array}{llllllll}66 & 65 & 32 & 11 & 13 & 2,3 & 2,1 & 20\end{array}$ $\begin{array}{llllllllll}47 & 45 & 25 & 11 & 15 & 8 & 12 & 1,8 & 2 & 20\end{array}$ $\begin{array}{llllllllll}55 & 53 & 30 & 12 & 16 & 10 & 13 & 1,7 & 2,2 & 20\end{array}$ $\begin{array}{llllllll}60 & 60 & 33 & 12 & 18 & 2,3 & 2,1 & 20\end{array}$ $\begin{array}{llllllllll}57 & 58 & 31 & 12 & 17 & 11 & 13 & 2,2 & 2,1 & 20\end{array}$ $\begin{array}{llllllllll}52 & 52 & 27 & 11 & 17 & 10 & 12 & 2 & 2,1 & 20\end{array}$ $\begin{array}{llllllllll}61 & 62 & 30 & 14 & 19 & 10 & 15 & 2 & 2,7 & 20\end{array}$ $\begin{array}{llllllllll}65 & 65 & 32 & 12 & 20 & 12 & 14 & 2,2 & 2,4 & 20\end{array}$ $\begin{array}{lllllllll}55 & 55 & 30 & 13 & 15 & 10 & 1,8 & 2,3 & 20\end{array}$ $\begin{array}{llllllllll}53 & 54 & 30 & 11 & 16 & 9 & 12 & 1,9 & 2,3 & 21\end{array}$ $\begin{array}{llllllllll}45 & 43 & 21 & 10 & 13 & 9 & 9 & 1,8 & 1,8 & 19\end{array}$ $\begin{array}{llllllllll}41 & 41 & 25 & 10 & 13 & 8 & 10 & 1,6 & 1,4 & 20\end{array}$ $\begin{array}{llllllllll}42 & 40 & 22 & 10 & 11 & 9 & 9 & 1,6 & 1,6 & 17\end{array}$ $\begin{array}{llllllllll}42 & 45 & 24 & 10 & 15 & 8 & 9 & 1,7 & 1,4 & 20\end{array}$ $\begin{array}{llllllllll}42 & 40 & 20 & 10 & 13 & 6 & 7 & 1,1 & 1,2 & 22\end{array}$ $\begin{array}{llllllllll}34 & 30 & 18 & 9 & 11 & 7 & 7 & 1 & 1 & 20\end{array}$ 


\section{Aequipecten opercularis}

\begin{tabular}{|c|c|c|c|c|c|c|c|c|c|}
\hline \multicolumn{10}{|c|}{ Valva Derecha } \\
\hline the & L & $\begin{array}{l}\text { margen } \\
\text { ant. }\end{array}$ & $\begin{array}{l}\text { Aur. } \\
\text { Ant. }\end{array}$ & & ur. & & cost. & L. & $\begin{array}{l}\mathrm{n}^{0} \\
\text { costillas }\end{array}$ \\
\hline & & & $\mathrm{H}$ & $\mathrm{L}$ & $\mathrm{H}$ & $\mathrm{L}$ & & & \\
\hline 42 & 42 & 24 & 8 & 15 & 8 & 9 & 1,7 & 1,5 & 16 \\
\hline 24 & 24 & 12 & 4 & 7 & 5 & 5 & 0,8 & 1 & 18 \\
\hline 32 & 31 & 16 & 5 & 10 & 6 & 7 & 0,6 & 0.9 & 19 \\
\hline 28 & 30 & 24 & 4 & 9 & 6 & 7 & 1 & 0,6 & 18 \\
\hline 31 & 32 & 16 & 5 & 10 & 5 & 7 & 0.9 & 0,7 & 19 \\
\hline 33 & 32 & 17 & 5 & 10 & 7 & 8 & 1,1 & 1,2 & 15 \\
\hline 32 & 32 & 17 & & & 7 & 7 & 1 & 1,1 & 15 \\
\hline 22 & 21 & 11 & 4 & 7 & 5 & 5 & 0,5 & 0,7 & 18 \\
\hline 53 & 51 & 22 & 5 & 11 & 8 & 9 & 2 & 2 & 18 \\
\hline 32 & 33 & 18 & 6 & 11 & & & 1,2 & 1,4 & 15 \\
\hline 37 & 38 & 19 & 5 & 10 & 6 & 9 & 1,1 & 1,1 & 19 \\
\hline 33 & 32 & 17 & 6 & 14 & 7 & 9 & 1 & 1,3 & 17 \\
\hline 32 & 32 & 15 & 5 & 10 & 6 & 8 & 1 & 1,1 & 20 \\
\hline 50 & 53 & 22 & 8 & 15 & 10 & 11 & 2 & 1,6 & 20 \\
\hline 20 & 19 & 10 & 3 & 6 & 3 & 4 & 0,5 & 0,5 & 19 \\
\hline 31 & 31 & 15 & 5 & 9 & 7 & 7 & 0,9 & 1,3 & 18 \\
\hline 48 & 48 & 27 & 8 & 16 & 9 & 12 & 1,8 & 2 & 16 \\
\hline 40 & 40 & 22 & 6 & 10 & 7 & 9 & 1.9 & 1,3 & 17 \\
\hline 30 & 31 & 17 & 5 & 9 & 7 & 8 & 1,4 & 1,5 & 17 \\
\hline 33 & 32 & 19 & 6 & 13 & 8 & 8 & 1,5 & 1,4 & 17 \\
\hline 50 & 50 & 24 & 7 & 15 & 10 & 12 & 2,1 & 1,7 & 18 \\
\hline 32 & 33 & 18 & 6 & 11 & 5 & 7 & 15 & 1 & 19 \\
\hline 35 & 36 & 19 & 8 & 10 & 7 & 8 & 1,6 & 1,2 & 18 \\
\hline 28 & 28 & 15 & & & 5 & 6 & 1,1 & 1 & 17 \\
\hline 30 & 30 & 17 & 6 & 10 & 4 & 6 & 1 & 1 & 19 \\
\hline 62 & 66 & 28 & 9 & 16 & 9 & 10 & 2,2 & 1,9 & 19 \\
\hline 40 & & 20 & 7 & 12 & 6 & 8 & 1,8 & 1,8 & 18 \\
\hline 66 & 69 & 30 & 10 & 20 & 10 & 18 & 2,3 & 2 & 17 \\
\hline 53 & 53 & 26 & 9 & 17 & 10 & 13 & 2,1 & 1,7 & 16 \\
\hline 31 & 32 & 19 & 7 & 11 & 5 & 9 & 1,6 & 1 & 16 \\
\hline 40 & 38 & 20 & 7 & 13 & 7 & 10 & 1,7 & 1,6 & 15 \\
\hline 37,1 & 37,3 & 19,2 & 6,2 & 11,6 & 6,8 & 8,5 & 1,4 & 1,3 & 17,5 \\
\hline
\end{tabular}

Valva Izquierda

\begin{tabular}{|c|c|c|c|c|c|c|c|c|c|}
\hline \\
\hline $\mathrm{H}$ & L & $\begin{array}{l}\text { margen } \\
\text { ant. }\end{array}$ & $\begin{array}{l}\text { Aur. } \\
\text { Ant. }\end{array}$ & & Aur. & & cost. & $\begin{array}{l}\mathrm{L} . \\
\text { interc. }\end{array}$ & $\begin{array}{l}\mathrm{n}^{0} \\
\text { costillas }\end{array}$ \\
\hline & & & $\mathrm{H}$ & $\mathrm{L}$ & $\mathrm{H}$ & $\mathrm{L}$ & & & \\
\hline 40 & 40 & 20 & 7 & 10 & 5 & 6 & 1,3 & 1,4 & 20 \\
\hline 41 & 41 & 22 & 7 & 10 & & & 1,6 & 1,2 & 18 \\
\hline 38 & 37 & 22 & & & 7 & 9 & 1,3 & 1,5 & 16 \\
\hline 36 & 36 & 20 & 7 & 10 & 6 & 7 & 1,5 & 1 & 19 \\
\hline 19 & 19 & 12 & 3 & 4 & & & 0,7 & 0,5 & 16 \\
\hline 45 & 43 & 23 & 7 & 10 & 5 & 5 & 1.9 & 1,2 & 15 \\
\hline 69 & 64 & 33 & & & 10 & 10 & 2.3 & 2.5 & 15 \\
\hline 36 & 36 & 20 & & & 7 & 11 & 1,7 & 1,6 & 15 \\
\hline 34 & 35 & 20 & 6 & 7 & 6 & 9 & 1,5 & 1,3 & 18 \\
\hline 39 & 40 & 20 & 8 & 11 & 7 & 10 & 1,4 & 1,4 & 17 \\
\hline 35 & 34 & 12 & 7 & 7 & 5 & 7 & 1,1 & 1,3 & 20 \\
\hline 21 & 21 & 12 & 5 & 6 & 4 & 5 & 0,7 & 0,6 & 18 \\
\hline 25 & 26 & 115 & 6 & 8 & 5 & 6 & 1 & 1 & 18 \\
\hline 29 & 30 & 16 & 6 & 8 & 5 & 7 & 1,2 & 1,2 & 18 \\
\hline 30 & 32 & 16 & 7 & 8 & 6 & 8 & 0,8 & 1,4 & 18 \\
\hline 41 & 41 & 22 & 8 & 14 & 9 & 10 & 1,6 & 1,5 & 15 \\
\hline 24 & 25 & 13 & & & 5 & 7 & 0,7 & 0,7 & 20 \\
\hline 30 & 32 & 15 & 7 & 10 & 5 & 8 & 1,4 & 0,9 & 16 \\
\hline 35 & 36 & 19 & 7 & 11 & 7 & 9 & 1,1 & 1 & 21 \\
\hline 53 & 54 & 30 & 9 & 14 & 9 & 12 & 2,4 & 1,6 & 18 \\
\hline 25 & 24 & 12 & 4 & 6 & 3 & 5 & 0,9 & 0,9 & 15 \\
\hline 48 & 47 & 27 & 9 & 15 & 9 & 11 & 1,6 & 1,9 & 15 \\
\hline 42 & 40 & 19 & 7 & 12 & 7 & 8 & 1,8 & 1,5 & 15 \\
\hline 64 & 68 & 36 & 9 & 13 & & & 2,3 & 2 & 18 \\
\hline 36 & 35 & 19 & 6 & 11 & 6 & 8 & 1 & 1 & 18 \\
\hline 47 & 45 & 23 & 8 & 11 & 7 & 9 & 1,6 & 1,7 & 17 \\
\hline 42 & 41 & 22 & & & 6 & 8 & 1,4 & 1,4 & 19 \\
\hline 56 & 55 & 27 & 10 & 16 & 9 & 14 & 1,9 & 1,9 & 14 \\
\hline 69 & 72 & 30 & 10 & 17 & 10 & 17 & 2,1 & 2,3 & 16 \\
\hline 39,6 & 39,6 & 24,0 & 7,1 & 10,4 & 6,5 & 8,7 & 1,4 & 1,4 & 17,2 \\
\hline
\end{tabular}

\section{Chlamys multistriata}

Valva Derecha

\begin{tabular}{|c|c|c|c|c|c|c|c|c|c|}
\hline \multirow[t]{2}{*}{ H } & \multirow[t]{2}{*}{$\mathrm{L}$} & $\begin{array}{l}\text { margen } \\
\text { ant. }\end{array}$ & $\begin{array}{l}\text { Aur. } \\
\text { Ant. }\end{array}$ & & $\begin{array}{l}\text { ur. } \\
\text { ost. }\end{array}$ & & \multirow[t]{2}{*}{ cost. } & \multirow[t]{2}{*}{$\begin{array}{l}\mathrm{L} . \\
\text { interc. }\end{array}$} & \multirow[t]{2}{*}{$\begin{array}{l}\mathrm{n}^{0} \\
\text { costillas }\end{array}$} \\
\hline & & & $\mathrm{H}$ & $\mathrm{L}$ & $\mathrm{H}$ & $\mathrm{L}$ & & & \\
\hline 29 & 21 & 13 & 5 & 8 & 5 & 4 & 0,5 & 0,4 & 22 \\
\hline 24 & 20 & 15 & 6 & 7 & 4 & 4 & 0,5 & 0,7 & 27 \\
\hline 29 & 24 & 17 & 6 & 8 & 5 & 4 & & & 31 \\
\hline 42 & 39 & 20 & 9 & 13 & & & & & 42 \\
\hline 28 & 25 & 16 & 7 & 10 & 5 & 4 & & & 22 \\
\hline 30 & 25 & 18 & 6 & 10 & 4 & 3 & & & 35 \\
\hline 18 & 16 & 11 & 3 & 5 & & & & & 28 \\
\hline 28,6 & 24,3 & 15,7 & 6,0 & 8,7 & 4,6 & 3,8 & 0,5 & 0,6 & 29,6 \\
\hline
\end{tabular}

Valva Izquierda

\begin{tabular}{|c|c|c|c|c|c|c|c|c|}
\hline $\mathrm{H}$ & L & $\begin{array}{l}\text { margen } \\
\text { ant. }\end{array}$ & $\begin{array}{l}\text { Aur. } \\
\text { Ant. }\end{array}$ & & $\begin{array}{l}\text { ur. } \\
\text { ost. }\end{array}$ & L cost. & $\begin{array}{l}\text { L. } \\
\text { interc. }\end{array}$ & $\begin{array}{l}\mathrm{n}^{0} \\
\text { costillas }\end{array}$ \\
\hline & & & $\mathrm{H}$ & $\mathrm{L}$ & $\mathrm{H}$ & $\mathrm{L}$ & & \\
\hline 37 & & & 10 & 10 & 7 & 5 & & 41 \\
\hline 28 & 22 & 15 & 7 & 8 & 5 & 5 & & 33 \\
\hline 39 & 32 & 20 & 10 & 12 & 7 & 7 & & 35 \\
\hline 20 & 16 & 10 & 4 & 7 & 5 & 3 & & 32 \\
\hline 31 & 25 & 17 & 9 & 9 & 4 & 5 & & 36 \\
\hline 42 & 39 & 20 & 9 & 12 & & & & 42 \\
\hline 29 & 25 & 15 & 8 & 9 & 4 & 4 & & 24 \\
\hline 29 & 24 & 14 & 7 & 9 & 6 & 4 & & 27 \\
\hline 25 & 19 & 12 & 7 & 6 & 5 & 4 & & 26 \\
\hline 31,1 & 25,3 & 15,4 & 7,9 & 9,1 & $\overline{5,4}$ & 4,6 & & 32,9 \\
\hline
\end{tabular}

\section{Flexopecten flexuosa}

\section{Valva Derecha}

\begin{tabular}{|c|c|c|c|c|c|c|c|c|c|c|}
\hline & & $\begin{array}{l}\text { margen } \\
\text { ant. }\end{array}$ & $\begin{array}{l}\text { Aur. } \\
\text { Ant. }\end{array}$ & & $\begin{array}{l}\text { ur. } \\
\text { ost. }\end{array}$ & & L cost. & $\begin{array}{l}\text { L. } \\
\text { interc. }\end{array}$ & & ostillas \\
\hline & & & $\mathrm{H}$ & $\mathrm{L}$ & $\mathrm{H}$ & $\mathrm{L}$ & & & & \\
\hline 20 & 20 & 15 & 6 & 8 & 5 & 8 & 2.8 & & & 4 \\
\hline 29 & 31 & 20 & & & & & 4,8 & 3 & & 4 \\
\hline 29 & 31 & 19 & 7 & 9 & 7 & 9 & 4,8 & 3 & & 4 \\
\hline 26 & 27 & 17 & & & 6 & 7 & 3,1 & & & 5 \\
\hline 26 & 27,3 & 17,8 & 6,5 & 8,5 & 6 & 8 & 3,9 & 3 & & 4,3 \\
\hline
\end{tabular}

Valva Izquierda

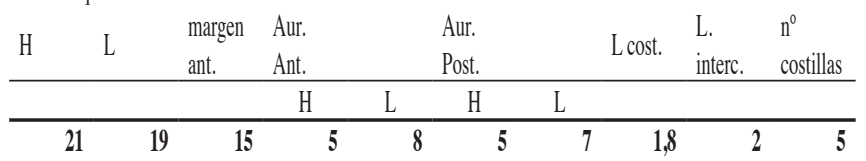




\section{Aequipecten scabrella}

\begin{tabular}{|c|c|c|c|c|c|c|c|c|c|}
\hline \multicolumn{10}{|c|}{ Valva Dere } \\
\hline $\mathrm{H}$ & $\mathrm{L}$ & $\begin{array}{l}\text { margen } \\
\text { ant. }\end{array}$ & $\begin{array}{l}\text { Aur. } \\
\text { Ant. }\end{array}$ & & $\begin{array}{l}\text { Aur. } \\
\text { Post. }\end{array}$ & & cost. & $\begin{array}{l}\mathrm{L} . \\
\text { interc. }\end{array}$ & $\begin{array}{l}\mathrm{n}^{0} \\
\text { costillas }\end{array}$ \\
\hline & & & $\mathrm{H}$ & $\mathrm{L}$ & $\mathrm{H}$ & $\mathrm{L}$ & & & \\
\hline 21 & 22 & 10 & 4 & 7 & 4 & 5 & 1 & 1 & 13 \\
\hline 33 & 40 & 20 & & & 8 & 9 & 1,5 & 1,5 & 15 \\
\hline 23 & 30 & 15 & 5 & 10 & 6 & 7 & 1,5 & 1,3 & 15 \\
\hline 23 & 24 & 13 & 4 & 9 & 6 & 7 & 1 & 1,1 & 14 \\
\hline 30 & 31 & 16 & 5 & 10 & 6 & 7 & 1,5 & 1,4 & 14 \\
\hline 27 & 29 & 16 & 5 & 10 & & & 1,7 & 1,1 & 16 \\
\hline 34 & 36 & 19 & 5 & 10 & 7 & 8 & 1,8 & 1,3 & 13 \\
\hline 23 & 24 & 14 & 4 & 8 & 5 & 5 & 1 & 1 & 14 \\
\hline 27 & 28 & 15 & & & 6 & 7 & 1,2 & 1,4 & 14 \\
\hline 31 & 31 & 18 & 5 & 11 & 7 & 7 & 1,5 & 1,2 & 14 \\
\hline 22 & 23 & 12 & 4 & 8 & 5 & 6 & 1 & 1,2 & 14 \\
\hline 20 & 20 & 12 & 3 & 8 & 4 & 5 & 1 & 0,8 & 14 \\
\hline 23 & 24 & 14 & 4 & & 5 & 6 & 1 & 0,9 & 15 \\
\hline 24 & 25 & 15 & 4 & 9 & 6 & 6 & 1,3 & 0.9 & 14 \\
\hline 23 & 23 & 14 & 4 & 9 & 6 & & 1,1 & 0.9 & 14 \\
\hline 24 & 25 & 16 & 4 & 9 & 6 & 6 & 1,3 & 1 & 15 \\
\hline 27 & 28 & 17 & 5 & 9 & 6 & 7 & 1,3 & 1 & 13 \\
\hline 20 & 19 & 13 & 3 & 7 & 4 & 6 & 0,9 & 0,6 & 14 \\
\hline 44 & 46 & 26 & 8 & 15 & 10 & 10 & 1,6 & 2 & 13 \\
\hline 24 & 26 & 14 & 5 & 8 & 6 & 7 & 1,4 & 1 & 12 \\
\hline 37 & 39 & 21 & & 7 & 8 & 8 & 1,9 & 1,7 & 13 \\
\hline 22 & 22 & 14 & 4 & 8 & 5 & 5 & 0,9 & 1,3 & 14 \\
\hline 28 & 30 & 16 & 5 & 10 & 7 & 7 & 1,2 & 1,2 & 14 \\
\hline 28 & 29 & 18 & & & & & 1,2 & 1,1 & 13 \\
\hline 37 & 40 & 20 & 7 & 11 & 8 & 9 & 2,3 & 1,9 & 11 \\
\hline 27 & 28 & 17 & 5 & 9 & 6 & 5 & 1,2 & 1,2 & 13 \\
\hline 32 & 35 & 20 & 8 & 11 & 6 & 7 & 1,8 & 1,5 & 13 \\
\hline 24 & 26 & 19 & 5 & 8 & 4 & 6 & 1,3 & 1 & 15 \\
\hline 25 & 26 & 15 & 5 & 5 & 9 & 6 & 1,2 & 0.9 & 15 \\
\hline 30 & 34 & 19 & 6 & 10 & 4 & 7 & 1,8 & 1,8 & 14 \\
\hline 27,1 & 28,8 & 16,3 & 4,8 & 9,1 & 6,1 & 6,7 & 1,3 & 1,2 & 13,8 \\
\hline
\end{tabular}

\begin{tabular}{|c|c|c|c|c|c|c|c|c|c|}
\hline \multicolumn{2}{|c|}{ Valva Izquierda } & \multirow[b]{2}{*}{$\begin{array}{l}\text { margen } \\
\text { ant. }\end{array}$} & \multirow[b]{2}{*}{$\begin{array}{l}\text { Aur. } \\
\text { Ant. }\end{array}$} & \multirow{2}{*}{\multicolumn{2}{|c|}{$\begin{array}{l}\text { Aur. } \\
\text { Post. }\end{array}$}} & \multirow{2}{*}{\multicolumn{2}{|c|}{ L cost. }} & \multirow[b]{2}{*}{$\begin{array}{l}\mathrm{L} . \\
\text { interc. }\end{array}$} & \multirow{2}{*}{$\begin{array}{l}\mathrm{n}^{0} \\
\text { costillas }\end{array}$} \\
\hline $\mathrm{H}$ & L & & & & & & & & \\
\hline & & & $\mathrm{H}$ & L & & $\mathrm{L}$ & & & \\
\hline 21 & & 12 & $\overline{5}$ & 6 & 4 & 5 & 0,9 & 0,9 & 13 \\
\hline 21 & & 13 & 4 & 8 & 5 & 6 & 0,8 & 1,1 & 14 \\
\hline 27 & 2 & 15 & 6 & 10 & 7 & 6 & 1,1 & 1,3 & 13 \\
\hline 24 & 2 & 14 & 5 & 6 & 5 & 6 & 0,9 & 1,6 & 14 \\
\hline 23 & 2 & 14 & 5 & 8 & 5 & 6 & 1 & 1,2 & 15 \\
\hline 26 & 2 & 17 & 5 & 8 & 6 & 6 & 0,8 & 1.2 & 15 \\
\hline 34 & 3 & 19 & & & & & 1,5 & 2 & 14 \\
\hline 28 & 5 & 20 & 6 & 8 & 5 & & 1,6 & 1,5 & 14 \\
\hline 20 & & 13 & 5 & 6 & 5 & 5 & 0,8 & 1 & 15 \\
\hline 27 & 2 & 15 & 6 & 8 & 5 & 7 & 1 & 1,4 & 15 \\
\hline 41 & 4 & 26 & 9 & 10 & & & 2,4 & 2 & 15 \\
\hline 33 & 3 & 20 & 7 & & 7 & 8 & 1,4 & 19 & 14 \\
\hline 2. & 2 & 15 & 6 & 8 & 5 & 7 & 1,1 & 1,4 & 13 \\
\hline 37 & 4 & 20 & 7 & & 8 & 10 & 1,9 & 2.2 & 14 \\
\hline 20 & 2 & 12 & 5 & 6 & 4 & 5 & 0,5 & 15 & 14 \\
\hline 33 & 3 & 20 & 6 & 11 & 8 & 9 & 1,4 & 19 & 15 \\
\hline 40 & 4 & 21 & & & 9 & 10 & 1,7 & 2,3 & 15 \\
\hline 20 & 2 & 11 & 4 & 7 & 5 & 6 & 0,8 & 0.9 & 15 \\
\hline 30 & 3 & 18 & 6 & 10 & & & 1,3 & 1,3 & 16 \\
\hline 18 & 1 & 10 & 3 & 6 & 4 & 5 & 0,5 & 1 & 15 \\
\hline 23 & 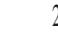 & 14 & 5 & 8 & 5 & 5 & 1 & 1,2 & 13 \\
\hline 33 & 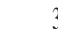 & 19 & 7 & 9 & 6 & 9 & 1,8 & 1,5 & 13 \\
\hline 3. & 3 & 20 & 8 & & 8 & 10 & 1,8 & 15 & 14 \\
\hline 20 & & 10 & 5 & 7 & 5 & 5 & 0,9 & 0.9 & 14 \\
\hline 22 & & 12 & 5 & 7 & 5 & 6 & 0,7 & 0.9 & 14 \\
\hline 18 & 1 & 11 & 4 & 6 & 4 & 5 & 0,8 & 1 & 16 \\
\hline 23 & 2 & 14 & 5 & 8 & 5 & 6 & 1 & 1 & 14 \\
\hline 28 & 3 & 17 & 7 & 9 & 6 & 7 & 1,2 & 1,8 & 15 \\
\hline 20 & 2 & 11 & 4 & 7 & 4 & 6 & 0,7 & 1 & 17 \\
\hline 3 & 3 & 18 & 6 & 10 & 6 & 9 & 1,4 & 1,8 & 14 \\
\hline 50 & 5 & 30 & 9 & 12 & & & 3,8 & 3 & 15 \\
\hline 27, & 28 & 16,2 & 5,7 & 8,0 & 5,6 & 6,7 & 1,2 & 1,5 & 14,4 \\
\hline
\end{tabular}

\section{Chlamys varia}

Valva Derecha

\begin{tabular}{|c|c|c|c|c|c|c|c|c|c|}
\hline $\mathrm{H}$ & L & $\begin{array}{l}\text { margen } \\
\text { ant. }\end{array}$ & $\begin{array}{l}\text { Aur. } \\
\text { Ant. }\end{array}$ & & $\begin{array}{l}\text { Aur. } \\
\text { Ost. }\end{array}$ & & cost. & $\begin{array}{l}\text { L. } \\
\text { interc. }\end{array}$ & $\begin{array}{l}\mathrm{n}^{0} \\
\text { costillas }\end{array}$ \\
\hline & & & $\mathrm{H}$ & $\mathrm{L}$ & $\mathrm{H}$ & $\mathrm{L}$ & & & \\
\hline 34 & 29 & 20 & 8 & 11 & 7 & 6 & 1 & 0,7 & 23 \\
\hline 43 & 36 & 24 & 9 & 14 & 6 & 7 & 1 & 1 & 22 \\
\hline 56 & 48 & 24 & 12 & 17 & 10 & 10 & 1,9 & 1,3 & 24 \\
\hline 50 & 44 & 25 & 9 & 16 & 7 & 9 & 1,4 & 1,4 & 18 \\
\hline 61 & 57 & 33 & & & 13 & 11 & 1,3 & 1,7 & 25 \\
\hline 34 & 28 & 18 & 7 & 12 & 4 & 6 & 1 & 0,9 & 23 \\
\hline 46 & 42 & 25 & 10 & 13 & 9 & 10 & 1 & 0,9 & 25 \\
\hline 59 & 54 & 30 & & & 7 & 14 & 1,3 & 1,7 & 22 \\
\hline 46 & 43 & 25 & 9 & 15 & & & 1 & 1 & 23 \\
\hline 40 & 34 & 21 & 9 & 14 & 7 & 7 & 1 & 1 & 25 \\
\hline 50 & 46 & 26 & 10 & 16 & 8 & 9 & 1,2 & 1,5 & 23 \\
\hline 47,2 & 41,9 & 24,6 & 9,2 & 14,2 & 7,8 & 89 & 1,2 & 1,2 & 23,0 \\
\hline
\end{tabular}

Valva Izquierda

\begin{tabular}{|c|c|c|c|c|c|c|c|c|c|}
\hline $\mathrm{H}$ & $\mathrm{L}$ & $\begin{array}{l}\text { margen } \\
\text { ant. }\end{array}$ & $\begin{array}{l}\text { Aur. } \\
\text { Ant. }\end{array}$ & & $\begin{array}{l}\text { ur. } \\
\text { ost. }\end{array}$ & & cost. & $\begin{array}{l}\text { L. } \\
\text { interc. }\end{array}$ & $\begin{array}{l}\mathrm{n}^{0} \\
\text { costillas }\end{array}$ \\
\hline & & & $\mathrm{H}$ & $\mathrm{L}$ & $\mathrm{H}$ & $\mathrm{L}$ & & & \\
\hline 50 & 45 & 25 & 12 & 15 & 9 & 7 & 1,1 & 1,1 & 22 \\
\hline 43 & 37 & 24 & 10 & 13 & 9 & 8 & 0,9 & 1 & 23 \\
\hline 45 & 39 & 20 & 10 & 11 & & & 1 & 1 & 23 \\
\hline 44 & 39 & 25 & 11 & 15 & 9 & 9 & 0,9 & 1 & 25 \\
\hline 59 & 52 & 30 & 14 & 18 & 10 & 12 & 1 & 1,6 & 22 \\
\hline 48 & 43 & 26 & 12 & 15 & 8 & 9 & 1,2 & 1,1 & 23 \\
\hline 61 & 55 & 27 & 14 & 19 & 11 & 12 & 1,1 & 1,6 & 23 \\
\hline 66 & 60 & 34 & & & & & 1 & 1,3 & 26 \\
\hline 63 & 58 & 32 & 12 & 16 & 9 & 11 & 1,4 & 1,8 & 20 \\
\hline 65 & 62 & 35 & 17 & 20 & 10 & 15 & 1,5 & 2 & 23 \\
\hline 39 & 31 & 17 & 10 & 13 & & & 0,8 & 1 & 23 \\
\hline 34 & 28 & 20 & 9 & 15 & & & 0,8 & 0,9 & 25 \\
\hline 33 & 28 & 20 & 8 & 9 & 10 & 9 & 0,7 & 0,5 & 26 \\
\hline 35 & 24 & 18 & 10 & 10 & 8 & 7 & 0,8 & 0,5 & 23 \\
\hline 39 & 32 & 23 & 10 & 12 & 8 & 7 & 0,8 & 0,8 & 22 \\
\hline 42 & 32 & 24 & 10 & 13 & 9 & 8 & 1 & 0,5 & 23 \\
\hline 28 & 22 & 15 & 7 & 8 & 5 & 4 & 0,7 & 0,5 & 23 \\
\hline 43 & 37 & 24 & 8 & 7 & & & 0,9 & 0,9 & 23 \\
\hline 46,5 & 40,2 & 24,4 & 10,8 & 13,5 & 8,8 & 9,1 & 1,0 & 1,1 & 23,2 \\
\hline
\end{tabular}




\section{Manupecten pesfelis}

Valva Derecha

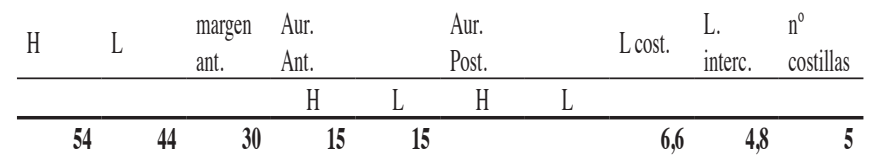

Valva Izquierda

\begin{tabular}{rrrrrrrrrr} 
H & L & $\begin{array}{l}\text { margen } \\
\text { ant. }\end{array}$ & $\begin{array}{l}\text { Aur. } \\
\text { Ant. }\end{array}$ & \multicolumn{2}{c}{$\begin{array}{l}\text { Aur. } \\
\text { Post. }\end{array}$} & L cost. $\begin{array}{l}\text { L. } \\
\text { interc. }\end{array}$ & $\begin{array}{l}\mathrm{n}^{0} \\
\text { costillas }\end{array}$ \\
\hline & & & H & L & H & L & & & \\
\hline 73 & 53 & 39 & & & 18 & 18 & 5,3 & 8,2 & 6 \\
32 & 29 & 20 & & & 11 & 11 & 3,4 & 4,5 & 5 \\
59 & 50 & 35 & 5 & 9 & 14 & 15 & 3,8 & 6,2 & 6 \\
\hline \hline 54,7 & $\mathbf{4 4 , 0}$ & $\mathbf{3 1 , 3}$ & $\mathbf{5 , 0}$ & $\mathbf{9 , 0}$ & $\mathbf{1 4 , 3}$ & $\mathbf{1 4 , 7}$ & $\mathbf{4 , 2}$ & $\mathbf{6 , 3}$ & $\mathbf{5 , 7}$
\end{tabular}

\section{Hinnites ercolanianus}

Valva Derecha

\begin{tabular}{|c|c|c|c|c|c|c|c|c|}
\hline $\mathrm{H}$ & & $\begin{array}{l}\text { margen } \\
\text { ant. }\end{array}$ & $\begin{array}{l}\text { Aur. } \\
\text { Ant. }\end{array}$ & & $\begin{array}{l}\text { ur. } \\
\text { ost. }\end{array}$ & L cost. & $\begin{array}{l}\text { L. } \\
\text { interc. }\end{array}$ & $\begin{array}{l}\mathrm{n}^{0} \\
\text { costillas }\end{array}$ \\
\hline & & & $\mathrm{H}$ & $\mathrm{L}$ & $\mathrm{H}$ & $\mathrm{L}$ & & \\
\hline 57,7 & 54,5 & 25 & 10 & 16 & 4 & 9 & & \\
\hline 59,7 & 55,5 & 17 & & & 3 & 11 & & \\
\hline 58,7 & 55 & 21 & 10 & 16 & 3,5 & 10 & & \\
\hline
\end{tabular}

Valva Izquierda

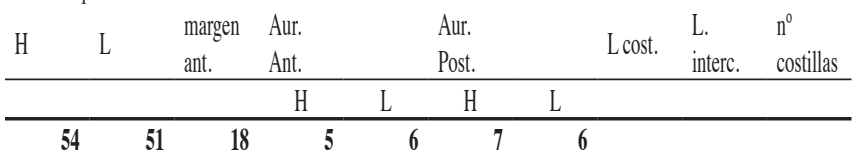

\section{Hinnites crispum}

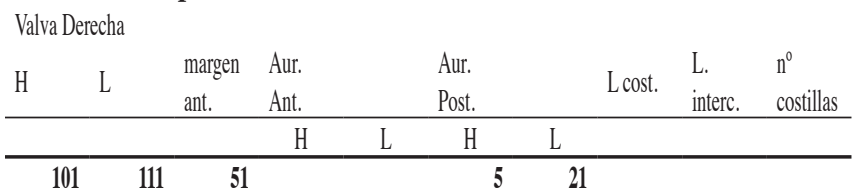

